Article

\title{
A Framework of Key Growth Factors for Small Enterprises Operating at the Base of the Pyramid
}

\author{
Michael D. van der Merwe ${ }^{1}$, Sara S. Grobbelaar ${ }^{2}, * \mathbb{E}$, Isabel A. Meyer ${ }^{3}$, Cornelius S.L. Schutte ${ }^{1}$ \\ and Konrad H. von Leipzig ${ }^{1}$ \\ 1 Department of Industrial Engineering, Stellenbosch University, Stellenbosch 7600, South Africa; \\ 16000293@sun.ac.za (M.D.v.d.M.); corne@sun.ac.za (C.S.L.S.); kvl@sun.ac.za (K.H.v.L.) \\ 2 Department of Industrial Engineering, Stellenbosch University AND DST-NRF Centre of Excellence in \\ Scientometrics and Science, Technology and Innovation Policy (SciSTIP), Stellenbosch 7600, South Africa \\ 3 Department of Industrial Engineering, Stellenbosch University AND CSIR Smart Mobility, \\ Pretoria 0001, South Africa; imeyer@csir.co.za \\ * Correspondence: ssgrobbelaar@sun.ac.za
}

Received: 20 August 2020; Accepted: 10 October 2020; Published: 10 November 2020

check for updates

\begin{abstract}
Enterprises operating at the Base of the Pyramid (BoP) find it difficult to simultaneously achieve economic (profitable growth) and social (poverty alleviation) outcomes. This study builds on a previously published systematic literature review that identified the key growth-promoting factors of the Small, Medium, and Micro Enterprises (SMMEs) operating in this space. A Grounded Theory Approach was followed to identify six core focus areas, which form the basis of a practical framework to evaluate SMMEs at the BoP, namely: Business modelling; business strategy; innovation; marketing; strategic alliances; and sustainable development. Expert screening interviews were conducted to evaluate the framework for credibility and confirmability. Thereafter, 57 for-profit South African enterprises were surveyed to empirically explore how SMMEs view and implement these framework components. The outcome of the study is a validated high growth-promoting BoP portfolio framework against which SMME owners can evaluate their enterprises to identify areas of growth and development.
\end{abstract}

Keywords: SMMEs; growth; evaluation tool; framework; base of the pyramid; sustainable enterprise growth

\section{Introduction and Problem Statement}

\subsection{Background and South African Context}

Conventional trickle-down theory has proven ineffective in reducing social inequalities and, although poverty has reduced globally under capitalist systems, wealth distributions have become increasingly skewed, with $50 \%$ of the world's wealth in the hands of $1 \%$ of individuals [1]. Prahalad and Hammond suggest that wealth distribution may be viewed as an economic pyramid in which more than 4 billion people, who live on less than $\$ 2$ a day, may be referred to as the Base of the Pyramid (BoP) $[2,3]$.

An example of a country where these inequalities are especially pronounced is South Africa. South Africa has a strong formal sector, its economy is quite advanced, and it has a strong financial sector and a good higher education sector. Regulations governing business activity are generally mature and well enforced $[4,5]$.

However, even though considerable progress has been made since the mid-1990s to improve the well-being of citizens, 55.5\% of South Africans still lived in poverty in 2017, surviving on less than 
$\$ 2$ per day (2017 prices). South Africa's Gini coefficient is 0.63, making it one of the most unequal countries in the world (World Bank, 2020). South Africa's unemployment rate remains high at 30\% in 2020 [6], it has a basic education system that perpetuates inequality [7], operates a public health system under pressure, and has high crime rates. Given the complexity of these socio-economic challenges, which were compounded by the COVID-19 pandemic, the government is ill-equipped to resolve them on its own, so as to facilitate sustained economic growth.

South Africa can thus be described by prevalent state and market failure. The South African government has an annual budget of R11.67 Trillion, of which R1.01 Trillion is spent on social services [8]. Taking into consideration that the budget deficit is already $24 \%$, it seems that the social need is greater than what the South African economy or government can provide for.

Despite efforts to intervene, the dichotomy in the economy remains, and market forces have not been able to bridge the divides and create a prosperous, equitable economy to support the poor. The BoP presents an inherently different and riskier business environment, making it arguably more difficult for small, medium, and micro-sized enterprises (SMMEs) to perform well-hence the focus of this study on a decision-making framework to aid SMME owners to operate and grow their businesses at the BoP (South Africa's Department of Trade and Industry defines SMMEs according to the National Small Business Act 102 of 1996 [9], as amended in the National Small Business Amendment Act 29 of 2004, wherein the term small enterprise means: A separate and distinct business entity, together with its branches or subsidiaries, if any, including co-operative enterprises [and non-governmental organizations], managed by one owner or more [which, including its branches or subsidiaries, if any, is] predominantly carried on in any sector or subsector of the economy ... classified as a micro-, a very small, a small or a medium enterprise. This is stipulated by the criteria (including number of employees, turnover, and value of assets) which vary depending on the industry sector the enterprise primarily acts in).

\subsection{Study Aim and Objectives}

Statistical analyses by the World Bank's International Monetary Fund [10] and the United Nations Conference on Trade and Development [11] show that it is consistently the most difficult to do business in countries with large BoP markets, primarily due to macro-environmental factors. Impediments include economic, financial, political, governance, and cultural factors [12-14]. These difficulties are compounded by the risk and uncertainty inherent in the BoP market [15-17].

Although initial literature mostly focused on ways of approaching the BoP as a viable market [2,18], recent evolutions of the concept have extended this purely market-based view [19-21]. The BoP concept shifted from the original $\mathrm{BoP}$ (the fortune at the base of the pyramid) to BoP 2 (Fortune with the BoP) and BoP 3 (Sustainable Development through innovation and entrepreneurship).

Enterprises operating at the BoP struggle to achieve the dual goals of sustained profitable growth and sustainable poverty alleviation. Profitable enterprise action at the BoP is certainly not a new concept and, although the BoP approach has been improved upon by scholars and practitioners alike, there seems to be no universal consensus or readily available tools for a structured approach to achieving profitability and sustainable poverty alleviation [2,22,23].

Studies of the BoP have mainly focused on the role of Multi-National Corporations (MNCs), while the few that considered the role of SMMEs have limited their research to the development of business models for contextually specific enterprises [24]. As far as could reasonably be determined, no decision support framework for SMME owners operating at the BoP existed at the time of our study, nor was there any indication of one specifically tailored to the unique context of South Africa.

The main research questions of this study are therefore stated as:

- What are the growth-promoting factors that will assist SMMEs operating at the BoP towards attaining higher, lasting growth and socio-economic development?

- How can these growth-promoting factors be incorporated in a coherent framework to aid SMME decision makers to achieve sustainable growth? 
This article presents a conceptual theoretical framework, based on an earlier-published systematic literature review (see [24]) in which the key factors that promote high growth in SMMEs at the BoP were identified, namely: business modelling; business strategy; innovation; marketing; strategic alliances; and sustainable development. From these concepts, a framework outline was populated with growth factor dimensions. The aim of this article is to present the evaluation of the framework, based on the analysis of a survey of 57 for-profit South African enterprises as well as expert interviews. The study delivered a high growth-promoting BoP framework to guide SMME owners in a structured approach to evaluate SMMEs operating at the BoP, so as to achieve sustainable and profitable growth.

The article is structured as follows: The methodology is outlined in Section 2, followed by a summary of the framework (Section 3). The framework evaluation is discussed in Section 4, and Section 5 concludes.

\section{Methodology}

A comprehensive body of literature informs the qualitative derivation of theory from text and data [25,26], and provides systematic methods for building conceptual frameworks [27]. Grounded Theory methods $[25,26]$ are suitable to developing theories of relationships among multidisciplinary concepts, as they share constructivist and interpretivist philosophical positions, making them useful in conceptual framework synthesis [28]. A Grounded Theory-based approach was thus followed to develop the framework and eventual management tool, using the Conceptual Framework Analysis (CFA) approach proposed by Jabareen [27], is an eight-phase process. The phases are structured into three parts, namely: (1) Understanding the landscape (qualitative); (2) developing the framework; and (3) evaluating the framework (mostly quantitative), as well as their objectives and outcomes, as shown in Table 1.

Table 1. The eight phases of framework development.

\begin{tabular}{|c|c|c|c|c|c|}
\hline & Phase & Description & Objective & Outcomes & Location in Article \\
\hline \multirow[t]{3}{*}{$\begin{array}{c}\text { Part 1: } \\
\text { Understand } \\
\text { Landscape }\end{array}$} & 1 & $\begin{array}{l}\text { Map the selected } \\
\text { data sources }\end{array}$ & $\begin{array}{l}\text { Identify relevant } \\
\text { literature regarding the } \\
\text { growth factors for } \\
\text { SMMEs }\end{array}$ & $\begin{array}{c}\text { A literature review of } \\
\text { multiple applicable } \\
\text { literature items }\end{array}$ & $\begin{array}{l}\text { Phases } 1 \text { to } 3 \text { : } \\
\text { Earlier publication [24] }\end{array}$ \\
\hline & 2 & $\begin{array}{l}\text { Read and categorize } \\
\text { the selected data }\end{array}$ & Identify data categories & $\begin{array}{l}\text { Coded studies, based on } \\
\text { keywords and use of Atlas.ti }\end{array}$ & \\
\hline & 3 & $\begin{array}{l}\text { Identify and name } \\
\text { concepts }\end{array}$ & $\begin{array}{c}\text { Develop concepts } \\
\text { through an analysis of } \\
\text { the literature }\end{array}$ & to group concepts & $\begin{array}{c}\text { Outcome discussed in } \\
\text { Section } 3\end{array}$ \\
\hline \multirow[t]{2}{*}{$\begin{array}{l}\text { Part 2: Develop } \\
\text { Framework }\end{array}$} & 4 & $\begin{array}{l}\text { Deconstruct and } \\
\text { categorize concepts }\end{array}$ & $\begin{array}{c}\text { Identify main attributes, } \\
\text { characteristics, } \\
\text { assumptions, and roles } \\
\text { of each concept }\end{array}$ & $\begin{array}{l}\text { Broad categories of high } \\
\text { growth-promoting factors in } \\
\text { SMMEs operating at the BoP }\end{array}$ & \\
\hline & 5 & Integrate concepts & Group similar concepts & $\begin{array}{c}\text { Concepts integrated into } \\
\text { growth promoting factors } \\
\text { for SMMEs operating at the } \\
\text { BoP }\end{array}$ & Section 3 \\
\hline \multirow{3}{*}{$\begin{array}{c}\text { Part 3: } \\
\text { Evaluate } \\
\text { Framework }\end{array}$} & 6 & $\begin{array}{l}\text { Synthesize and } \\
\text { resynthesize }\end{array}$ & $\begin{array}{l}\text { Develop a conceptual } \\
\text { framework }\end{array}$ & $\begin{array}{l}\text { Conceptual framework, } \\
\text { based on clusters }\end{array}$ & Section 3 \\
\hline & 7 & $\begin{array}{l}\text { Evaluate and analyze } \\
\text { the conceptual } \\
\text { framework }\end{array}$ & $\begin{array}{c}\text { Refine the conceptual } \\
\text { framework through } \\
\text { feedback }\end{array}$ & $\begin{array}{l}\text { Refined framework, based } \\
\text { on semi-structured } \\
\text { interviews and a survey }\end{array}$ & Section 4 \\
\hline & 8 & $\begin{array}{c}\text { Develop } \\
\text { management } \\
\text { suggestions based on } \\
\text { empirical results }\end{array}$ & $\begin{array}{c}\text { Identify areas for focus } \\
\text { through evaluation of } \\
\text { the enterprise against the } \\
\text { framework }\end{array}$ & $\begin{array}{l}\text { Incorporates areas that are } \\
\text { difficult to implement or } \\
\text { have largely been ignored }\end{array}$ & $\begin{array}{l}\text { For application by } \\
\text { SMME owners }\end{array}$ \\
\hline
\end{tabular}

Phases 1 to 5 served as the foundation of conceptual framework development by allowing the collection, refinement, and analysis of identified literature sources, after which key concepts could be integrated into various clusters. The first iteration of the conceptual framework was constructed during Phase 6. Subsequently, Phase 7 documented the framework evaluation through the use of 5 semi-structured interviews and a survey with 57 responses. The final validated framework is ready for use by SMME owners to evaluate their enterprises. The sections that follow provide more information regarding the methodology that was adopted for the literature review, interviews, and survey. 


\subsection{Parts 1 and 2: Understand the Landscape and Develop the Framework}

The complete systematic literature review is described in an earlier publication [24] with some key elements of the literature review approach summarized here.

The following systematized literature review process was undertaken to arrive at a comprehensive list of enterprise growth promoting factors:

This systematized review methodology has been shown as appropriate for identifying a comprehensive list of literary works [29]. Google Scholar, Thomson Reuters' Web of Science, Elsevier's Scopus, Ebscohost, and ProQuest, which together cover multiple domains of science and social science, were selected for this study. In order to perform a thorough primary search and avoid leaving out important alternative wordings of the titles of literary works, the search phrase for the review was broken down into three components, namely, degree modifying, adjectival, and objectival components. For example, the phrase high growth enterprise can be broken down into the degree modifying component high, the adjectival component growth, and the objectival component enterprise. Table 2 lists the different components from which combinations were made and searched for.

Table 2. Search phrase components.

\begin{tabular}{ccc}
\hline Degree Modifier & Adjective & Objective \\
\hline high & grow (-ing, -th) & enterprise \\
accelerated & perform (-ing, -ance) & venture \\
rapid & success (-ful) & gazelle \\
fast & impact (-ing) & company \\
advanced & expand (-ing) & business \\
endogenous & develop (-ing) & firm \\
quick & entrepreneurial & organization \\
\hline
\end{tabular}

The search results were filtered by reading the abstract, and by briefly scanning the document as a whole to find any additional literary works that were deemed relevant to the topic. These literary works were then sorted into two groups, Influential Works (IWs) and Supporting Works (SWs), and further ranked and categorized to identify the appropriate factors (see Section 3).

\subsection{Part 3: Framework Evaluation-Methods for the Interviews and Survey}

\subsubsection{Interviews}

The researchers interviewed five experts to determine the framework's credibility and conformability. Experts were selected based on their years of experience in the areas of SMME development, exposure to the BoP market, and years of experience in sustainable enterprise planning, formation, development, and growth. The focus was on their background in management of the relevant areas, namely strategy, innovation, marketing, finances (venture capital and private equity), business partnerships, and organizational design/architecture.

Following each interview, the framework was updated in an iterative fashion. After five interviews, the framework had sufficiently stabilized to allow the survey to be formulated. The measures of performance that were defined through the framework development process informed the assessment that was conducted to determine if this point of stability has been reached. The changes required in each iteration were minimal, due to the very detailed and structured approach followed in the framework's development.

\subsubsection{Survey}

The survey was constructed by breaking down the conceptual framework into logical statements to reflect its primary requirements, where after the list was refined by reducing overlap. Respondents 
were asked to rank their opinion of the impact and managerial difficulty of various practices of the growth factors with regard to:

- The impact that each best practice has on growth; and

- How difficult each best practice is to manage effectively.

Owners and/or managers of South African social enterprises were surveyed. The majority of the social entrepreneur survey sample was constructed from respondents from the South African Breweries Foundation (SABF) database of social entrepreneurs. Other respondents were found via an ad hoc approach of scouring the internet for social enterprise award winners (e.g., the Schwab Foundation's South African winners). As the majority of the respondents came from the SABF database and other award-winning social enterprises, the credibility of the respondents was ensured.

A survey instrument was designed to incorporate all the key features of the framework at that point in time; this was aimed at assessing the framework's validity in an empirical manner, and at confirming the need for the framework, its reliability, its relevance, and its usefulness.

The survey instrument can be found in Supplementary A. The survey delivered 57 complete survey responses from social entrepreneurs operating at the BoP. The survey analysis included a frequency analysis as well as a statistical analysis, which explored variance and regressions.

\section{Understanding the Landscape-Framework Outline (Parts 1 and 2)}

The findings of the systematized literature review process upon which this article is based [24] revealed that, although there are many varying definitions of what constitutes high growth of an enterprise, there is a high level of convergence of the factors that promote such growth. These factors have also proven to be generally independent of the particular sector in which the enterprise operates. While the literature review is not repeated here, the manner is outlined by which results were used to inform the framework.

\subsection{Identifying Enterprise Growth Factors}

The comprehensive approach that was adopted to compile such factors from literary sources takes into account not only the popularity of the literary work through noting the citation count, but also the degree of linkage (cross referencing) between highly cited works. The identified literature was sorted into two groups.

The first group incorporated all literary works that were specifically related to enterprise growth, without considering the degree modifier. Literary sources in this group were labelled as Influential Works (IWs). The second group pertains to literary works that are supportive in nature, in that they contribute to building the theory that supports the claims of IWs; these works are therefore labelled as Supporting Works (SWs). Altogether, 114 IWs and 45 SWs were identified (to be found in Supplementary B).

Key Influential Works (KIWs) are the highest ranked IWs and have arbitrarily been chosen such that each growth factor is addressed at least twice. By working in descending order from the highest-ranked IWs, the minimum number of IWs necessary to ensure that each factor is addressed twice was found to be up to and including the IW with ID number 45 . These 45 IWs were thus established as KIWs.

The KIWs were determined to ensure that the frequency with which the characteristics are addressed in the top-rated IWs (i.e., the KIWs) can be compared to the overall frequency with which each characteristic is focused on in the IWs. If the two are proportional to one another, it is clear that the characteristics are well distributed throughout the range of IWs. Figure 1 affirms that the selected growth factors are well distributed among the literary works. 


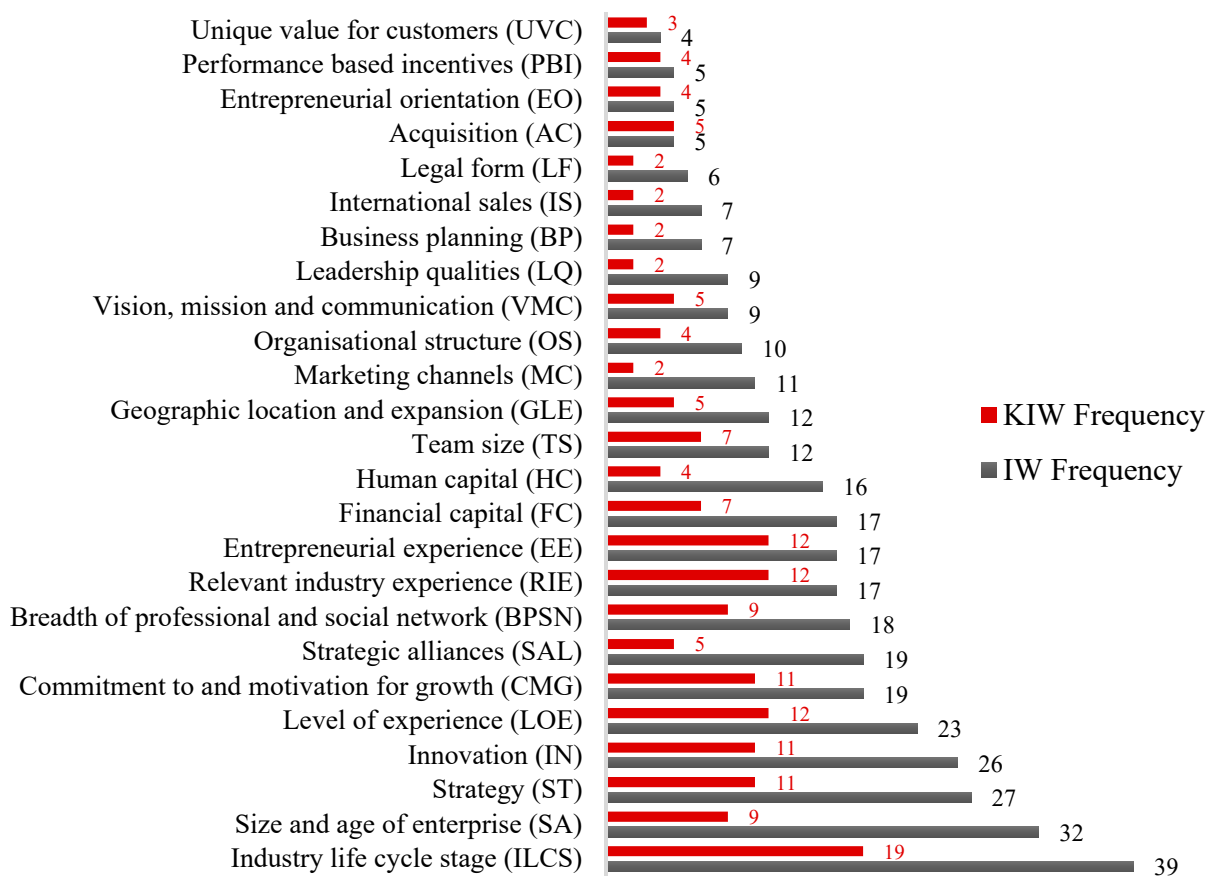

Figure 1. Key characteristic occurrence frequencies.

The systematized approach to compiling literary factors from literary sources was outlined in Figure 2. It is a rigorous approach that considers not only the popularity of the literary work by noting the citation count, but also the degree of linkage (cross referencing) between highly cited works. The approach is further strengthened by ensuring that new studies are not neglected due to what is known as the Matthew Effect. By modifying the citation counts with this factor, and incorporating the degree of linkage, it is an easy (albeit time consuming) process to arrive at a comprehensive set of factors selected from the identified and ranked literary works.

\begin{tabular}{|c|c|c|c|c|}
\hline $\begin{array}{l}1 \text { Compile a } \\
\text { comprehensive } \\
\text { literature base }\end{array}$ & $\begin{array}{l}2 \text { Rank } \\
\text { importance of } \\
\text { literary works }\end{array}$ & $\begin{array}{l}3 \text { Extract key } \\
\text { factors from } \\
\text { ranked literary } \\
\text { works }\end{array}$ & $\begin{array}{l}4 \text { Organise key } \\
\text { factors into } \\
\text { logical groupings }\end{array}$ & $\begin{array}{l}5 \text { Apply growth } \\
\text { factors to the } \\
\text { BOP }\end{array}$ \\
\hline $\begin{array}{l}\text { Add highly visible literary } \\
\text { works from reference lists } \\
\text { of alr eady identified } \\
\text { literary works }\end{array}$ & $\begin{array}{l}\text { According to: } \\
\text { 1. Citation count } \\
\text { 2. Linkage to other } \\
\text { scholars (times cited \& } \\
\text { times citing others) }\end{array}$ & $\begin{array}{l}\text { Show preference to more } \\
\text { highly ranked liter ary } \\
\text { works in determining } \\
\text { relevance of factors }\end{array}$ & $\begin{array}{l}\text { Look at: } \\
\text { 1. Internal vs. external } \\
\text { 2. Lifecycle phase } \\
\text { 3. Business vs. human } \\
\text { resource strategy relation }\end{array}$ & $\begin{array}{l}\text { Develop success } \\
\text { factors that promote } \\
\text { success of best } \\
\text { practices at the BOP }\end{array}$ \\
\hline
\end{tabular}

Figure 2. Systematized literature review process for enterprise growth literature.

These factors, which were found to promote high growth, were listed in the following four logical groupings:

Founder attributes: Leadership qualities; team size and synergy; relevant industry experience; level of education; entrepreneurial experience; entrepreneurial orientation, and; breadth of professional and social network;

Enterprise attributes: Size and age of the enterprise; legal form; geographic location and expansion; industry life cycle stage and market environment; financial capital; organizational structure; vision, mission, and communication, and; commitment to and motivation for growth;

Business practice factors: Strategy; strategic alliances; business planning; marketing; international sales; acquisition; creating unique value for customers, and; innovation;

Human resource factors: Human capital, and performance-based incentives.

The factors within each grouping are summarized in Figure 3. 

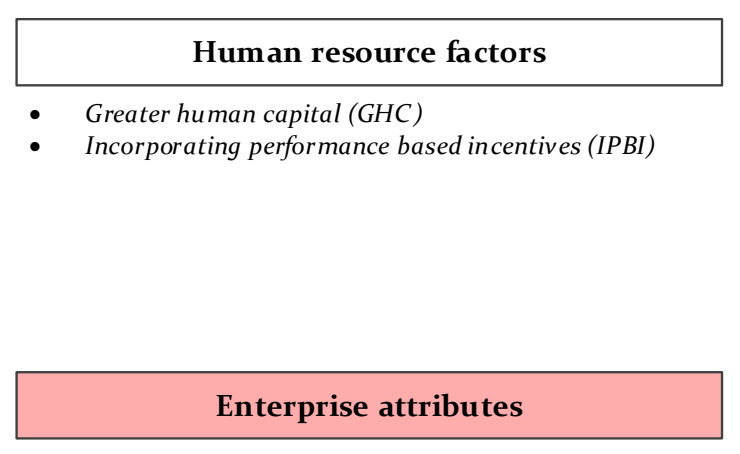

- Ideal vision, mission, and communication (IVMC)

- Commitment to and motivation for growth (CMG)

- Evolving organisational structure (EOS)

- Industry life cycle stage and market environment (ILCS)

- $\quad$ Limited liability legal form ( $L L L F)$

- Geographic location and expansion (GLE)

- Accessing financial capital (AFC)

- $\quad$ Reduced size and age (RSA)

\section{Founder attributes}

- Level of education (LOE)

- Relevant industry experience (RIE)

- Apt entrepreneurial experience (AEE)

- $\quad$ Synergistic team size (STS)

- Broad professional and social network (BPSN)

- Apt entrepreneurial orientation (AEO)

- $\quad$ Apt leadership qualities (ALQ)

\section{Business practice factors}

- Unique value creation for customers (UVC)

- Leveraging strategic alliances (LSA)

- Innovationfor continuous improvement (ICI)

- Holistic marketing capabilities (HMC)

- High acquisition propensity (HAP)

- Fostering international sales (FIS)

- Detailed business planning (DBP)

- Apt founding strategy (AFS)

Figure 3. Logical groupings of high growth promoting factors.

With a ranked list of high growth factors already organized into specific categories, it is possible to argue which of the aforementioned factors are most important, given the purpose and scope of this study.

A two-step process was followed. First, the growth promoting factors were classified into their respective fields within, or outside of, the scope of this research. Some factors span a number of fields, as would be expected. This step served to eliminate the factors that fell outside of the scope of this study. Second, the interrelationships among the within-scope factors were structured hierarchically, with considerations given to the frequency of occurrence in IWs and KIWs.

A number of factors were adopted to delimitate the study, and these were taken into account in defining the boundaries of Figure 4, including: Organizational size, influencing factors (internal factors within the direct control of the enterprise rather than external factors which are outside the direct control of the enterprise), business life cycle stage (focusing only on the start-up phase whereby the enterprise is already functional and has navigated through all the regulatory red tape, and is well positioned for moving into the growth-phase), and strategic focus (business strategy as opposed to human resource strategy).

\begin{tabular}{|c|c|c|c|c|}
\hline PRE START-UP PHASE & START-UP PHASE & POST START-UP PHASE & & \\
\hline & & & \multicolumn{2}{|c|}{$\begin{array}{l}\text { EXTERNAL } \\
\text { FACTORS }\end{array}$} \\
\hline\lceil & SA - UVC & 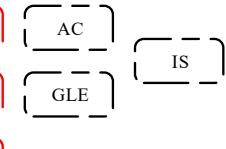 & 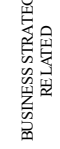 & \multirow{2}{*}{$\begin{array}{l}\text { INTERNAL } \\
\text { FACTORS }\end{array}$} \\
\hline 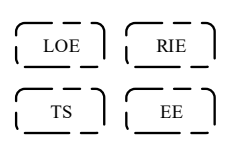 & 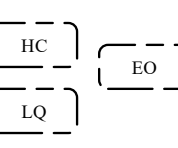 & & 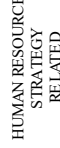 & \\
\hline
\end{tabular}

Figure 4. Organized enterprise growth factors.

From the list of 25 factors that arguably promote high growth, eight were within the scope of this research (marked in red in Figure 4). 
The following are the eight internal business factors (i.e., within the locus of control of the entrepreneur), and most relevant in the start-up phase of the enterprise life cycle (see the red factors in Figure 4):

Business planning (BP): Although important throughout the enterprise life cycle, planning is an iterative process that must consider multiple areas of concern as well as projections for the future functioning of the enterprise, making it ever so imperative in the start-up phase;

Financial capital (FC): Acquiring financial capital must occur during the pre-start-up and start-up phases to ensure smooth running of the enterprise during start-up;

Innovation (IN): This aspect plays a crucial role at all times. For young enterprises in the start-up phase with inherently less resources at their disposal, IN can provide the much-needed edge in the industry; for older post start-up phase enterprises, IN can maintain the enterprise's dominance;

Marketing capabilities (MC): Marketing has much to do with reaching and interacting with customers, which is pivotal in both the start-up and post start-up phases of the enterprise life cycle;

Size and age (SA): While this factor cannot be controlled, the literature has revealed the tendency of young enterprises to grow the most; this associates SA with the start-up phase;

Strategic alliances (SAL): SAL formation is critical in the start-up and post start-up phases of the enterprise; however, it is associated with relationships with role players outside the control of the enterprise, and is therefore seen as a jointly external and internal (business strategy related) factor;

Strategy (ST): ST includes both human resource and business ST, and is imperative regardless of the age of the enterprise; it is therefore relevant to both the start-up and post start-up phases of the enterprise life cycle;

Unique value for customers (UVC): The enterprise should be unique and build the customer base by winning over customers through increased value, especially during its early start-up phase.

From the systematized literature review, this list of eight factors were refined to arrive at five high-growth factors of importance to this study. These factors include business planning, business strategy, innovation, marketing, and strategic alliances.

Based on interviews aimed at validating the framework (see Section 4), as well as its high frequency of occurrence in the BoP 3 literature reviewed, sustainable development is an additional and explicit factor that was deemed important to include (opposed to being integrated in the other factors). Its importance relates to the need to foster a multi-modal sustainable view of growth at the BoP (i.e., social, economic, and environmental), and it was therefore included as a unique concern for further deliberation.

Sections 3.2-3.7 expands on each of the considerations that are deemed relevant and important for enterprise owners and managers in attaining high growth when targeting the BoP. These considerations were used to develop a list of requirements for growth. Thus, the aim of the next six sub-sections is to answer the question: How can each of these six factors be applied in the context of the BoP?

\subsection{Business Planning by Utilising Business Modelling}

Business planning provides a means of combining most of the fundamental necessities of the enterprise into a clear-cut and ordered set of procedures. A comprehensive plan is set out in a business model, which covers all the key areas of doing business. Thus, it is clearly of value to understand the role of business models for operating at the BoP [30].

It is important to carefully plan for the BoP enterprise's customer relationships. Here, the literature emphasizes direct engagement with the BoP, for example to test the viability of value propositions [31,32]. Business modelling allows for detailed planning of the management of customer relationships [33]. This is also closely related to the manner in which the enterprise defines channels to understand its engagement and communication with BoP customer segments when delivering a product, service, or combination thereof. This includes the creation of distribution channels along with, or even before, creating demand [34], and bringing the product and BoP customer closer together [35-37]. BoP enterprises also need to be cognizant of how to model revenue streams that relate to the income 
of BoP actors [38]. This entails balancing profitability with goals such as poverty alleviation and empowerment of BoP actors [39-42]. Further, it is of importance to determine key resources and manage the resource constraints that are likely to crop up, including raw material, financial, production, and human resource constraints [43]. Key partnerships are a strategic capability that entails engaging in horizontal and equal authority arrangements when developing solutions in close collaboration with BoP actors [44-47]. Key activities include strengthening the value chain [48]; investing in core competencies early and consistently [49]; building logistics and manufacturing infrastructure sensitive to BoP conditions; and deskilling of work for BoP co-creators and distributors [40].

\subsection{Business Strategy}

In formulating a business strategy for entering the BoP, it is necessary for founders to establish from the outset that they are in a business, with a profit motive. Here, some suggestion is made to follow a non-competitive approach to reduce competition [18] and thinking for-profit, and not to act as a charity or philanthropic institution would. Strategies must consider the underlying technology architectures for updating and upscaling the enterprise; further, the issue of leapfrogging upper-tier markets is mentioned as a strategic approach $[3,50,51]$.

In light of the above, some activities are presented by which to explore an uncontested market space. This study adopted the Blue Ocean Strategy as an activity system to find an uncontested market space, to minimize costs, and to maximize value at the BoP [52-54]. This requires incorporating the essential features of a good strategy, such as: (1) Outlining the strategic profile of the enterprise, industry, and current and potential competitors; this also entails assessing and understanding the needs of BoP livelihoods at the micro level [55]; (2) addressing key organizational hurdles for optimal strategy implementation; (3) determining competitive factors that can minimize or eliminate competition, such as low cost relationships with other BoP actors and overcoming the value-cost trade-off [53]; (4) getting into the field and actively engaging with stakeholders (in particular with BoP actors as consumers, employees, distributors, and suppliers) to build local embeddedness and capacity [56-58]; (5) creating new demand (market space) for products by considering non-customers, whilst focusing on both the differences and commonalities among what buyers value. This entails navigating the living environment of, and having low-cost access to, the BoP to facilitate lower prices $[35,59]$. The creation of demand also hinges on continuous access to affordable products in a resource-depleted environment [60]. This can be achieved by utilizing both formal and informal distribution channels [33,56,61].

\subsection{Innovation}

As innovation consistently contributes to successful and growing enterprises [62], it is understandably an important component of any business strategy that intends to target the BoP market. A number of reasons underlie the importance of innovation as a means of successfully exploiting new ideas when dealing with and selling to the BoP [63]. Ideas concerning successful products or services for the BoP are inherently more complex, as there are a number of unique hurdles that an enterprise must clear before the BoP can be pursued as a market.

It can therefore be argued that innovation takes place through a continuous cycle of improvement. Essentially, inclusive innovation efforts (regarding knowledge creation, acquisition, absorption, and distribution) must primarily aim to benefit individuals at the BoP and marginalized communities by leading to improved access to products, services, or economic benefit $[45,47,64-68]$.

It has been argued that innovation at the BoP is often incremental with a focus on diffusion, local needs, demand, and customer suitability [55]. Outcomes of the innovation process have been suggested as focusing on large price performance improvements [69], and on the development of frugal innovations where the entrepreneurs explore simpler, less expensive, more convenient value offerings [70].

The diffusion of innovations at the BoP is also a significant focus; here, innovations should be undertaken within an inclusive frame of discourse and knowledge [46,64,71]. Value offerings must 
exhibit compatibility, complexity, observability, relative advantage, and trialability to promote diffusion and adoption [72]. Further, it has been shown that innovation, alongside training, can be used to improve the impact of corporate social responsibility investment on their sustainability [73]. It could therefore be argued that the innovation process entails action pertaining to: (1) A needs assessment in close cooperation with the BoP to guide the innovation search process; (2) generating innovative solutions to social problems by utilizing a wide range of partners, search tools, and mechanisms (e.g., engaging at the grassroots level through multi-stakeholder engagement platforms); (3) applying a process for selecting the most appropriate innovative solution; (4) establishing stopping criteria to terminate too costly/unfruitful ideas, testing the robustness of proposed solutions, and reducing risk (key technical and market uncertainties); (5) capturing maximal value by maximizing compatibility (consistency) with existing norms and values of a wide range of stakeholders, while minimizing the need for new skills and knowledge to use/benefit from the innovative solution (e.g., by deskilling of work for BoP co-creators and distributors); (6) making the outcomes/results of innovation clearly visible to the potential buyer/user, and; (7) managing the process where potential BoP adopters can experiment with the innovation prior to investment $[5,21,69,74,75]$.

\subsection{Marketing Capabilities}

Marketing to the upper tiers of the economic pyramid is well documented and generally occurs in a highly competitive environment. It is widely acknowledged that price, product, promotion, and place are intrinsically important to any marketing plan. Whereas high-end markets are usually easily accessible and have a set of customers who will likely be able to afford a high price, this is usually not the case at the BoP. Instead, difficulties in each of these areas play a large role in the marketability of a product or service, thus redefining the way in which SMMEs need to reach their customers [76].

The BoP does not resemble the common consumerist market; therefore, it will, in most cases, not be sufficient to merely lower prices on existing high-end market products by reducing functional capabilities in product design, since customers at the BoP are also sensitive to product and service quality. The specific focus on Marketing ensures that the SMME arrives at a viable value offering for the BoP market. This focus addresses the steps to be taken to ensure that a feasible market is targeted, while also ensuring that a real need at the BoP is addressed [77,78]. It entails action to: (1) Develop a holistic view of marketing, by understanding all of its dimensions; (2) foster a customer-centric enterprise and targeting specific market segments [79-81]; (3) identify customer segments by behavioral and need characteristics and demographics; (4) market branding needs to then be developed in line with the segment being pursued, to maximize visibility and hone in on the market's specific desires; (5) establish appropriate channels to ensure market accessibility and overcoming access barriers to the BoP [58]. This may be done by utilizing both formal and informal distribution channels [33,56,61]; and (6) deliver along the dimensions of affordability, acceptability, availability, and awareness [34,76,82].

\subsection{Strategic Alliances}

Since many BoP targeting enterprises are substantially under-resourced and operating in an ecosystem that poses particularly new and unique difficulties in serving clients effectively, partnerships with numerous role-players are often vital to success. This enables the enterprise to gain access to much-needed expertise and resources. By forming alliances, SMME owners and managers can share their core competencies in an effective manner and bring about improved growth.

Cross-sector partnerships facilitate access to resources and capabilities [83], and institutional gaps (access to capital, technology, and managerial expertise) are best filled with diverse partners $[82,84,85]$. For example, NGOs may aid in better understanding the needs and behaviors of the BoP $[58,86]$; the civil and business sector is ideal for addressing customer needs; the public sector aids well with responding to the institutional environment [83]; and, finally, funding is more likely to come from NGOs and philanthropic institutions $[19,87]$. 
However, strategic alliances bring with them a heightened risk that the enterprise's core competencies could be opportunistically appropriated by the partner, which requires that a clear approach to managing the relationship is followed. By managing the relationship appropriately, risks can be mitigated, while gains are leveraged. This promotes the need for further research on the nature of strategic alliances at the BoP.

Strategic alliances relate the purposeful activities that the owner and managers of the BoP-targeting SMME must conduct in order to develop safe and productive alliances with strategic partners. The strategic alliance system describes that the following key areas should be addressed: (1) Determining if an alliance is strategically ideal-collaborating to gain capabilities, legitimacy, create new value, access local resources and markets, and cut costs may be reasons for looking for a partner [83,87]; (2) engaging in a process of evaluating and selecting partners-for example, consideration should be given to those who are open to learning, are mission driven, and are socially embedded, all of which are ideal traits for BoP partners [19]; (3) designing the alliance via contracts and negotiations. Here, consideration should be given to promoting long-term working relationships, training, education, empowerment, and skills transfer for partners [65,88,89]; and (4) managing, assessing, renewing, or potentially terminating the alliance. With respect to alliance management, the following are important: Network development; cultural aspects; communication; relational dynamics; knowledge management and learning; resource management; alliance performance evaluation; and risk management [90-94].

\subsection{The Importance of Sustainable Development at the BoP}

Inherent in all social entrepreneurship activities is a need for sustainable operations, and the pursuit of lasting poverty alleviation through SMME action is no exception. Sustainable development has become increasingly important to SMMEs for a number of reasons. The first of these is that many enterprises are assessed from a supply chain perspective-at a local scale, but also by global players for whom it is commercially important for sustainable development and a necessary requirement for entry into international markets.

Sustainable development also provides monetary benefits via increased efficiencies and conservation techniques, for example, energy, waste, and water. It provides access to new markets and competitive advantage, in that an enterprise might differentiate itself through the use of sustainable practices. Enterprises that practice sustainable development benefit on a global scale through increased brand recognition. Lastly, sustainability measures minimize enterprise risk in terms of financial, environmental, social, and even legal impacts, and opens up new opportunities as the visibility of the enterprise will facilitate easier access to financial capital.

Sustainable development is the conscious action to ensure that all of the SMME's activities are sustainable. The sustainable development system requires constant attention to ensure that the outcome of the enterprise, as well as each of its operations and choices of direction, are sustainable. This implies economic, social, and environmental feasibility on all counts. In essence, the system ensures that any changes are beneficial in all three dimensions, and that negative consequences are mitigated as far as possible. This needs to be done by: (1) Practically addressing the economic, social, and environmental needs of the poor; and (2) evaluating and promoting the long-term feasibility of the business from an economic, social, and environmental perspective [95-100].

\subsection{The Conceptual Framework}

The discussion in the preceding sections highlighted the rationale for incorporating each of the elements in a coherent conceptual framework. This framework is summarized in Figure 5, which outlines the detail of each of the six key factors for sustainable profitable growth at the BoP. 


\begin{tabular}{|l|}
\hline Business modelling \\
\hline - Describe core logic for creating and capturing value \\
- Identifying customer segments \\
- Define Channels \\
- Identify Customer Relationships \\
- Estimate Revenue Streams and Cost Structures \\
- Identify Key Partnerships \\
\hline
\end{tabular}

\begin{tabular}{|l|}
\hline Strategy \\
\hline - Document clear strategy to obtain goals and results \\
- Addressing key organisational hurdles \\
- Determine competitive factors to address competition \\
- Get in field to get first-hand experience \\
- Create new demand / market space for products and services \\
- Step-wise approach to strategy: \\
$\checkmark$ maximise buyer acceptability in design \\
$\checkmark$ ensure affordability \\
$\checkmark$ ensure accessibility \\
$\checkmark$ increase awareness \\
\hline
\end{tabular}

\begin{tabular}{|l|}
\hline Innovation \\
\hline - Innovating for new ideas and improve existing offers \\
- Getermine requirements \\
$\checkmark$ utilising multiple sources of innovation \\
$\checkmark$ engaging with the poor \\
$\checkmark$ ranking and selecting top innovative solutions \\
- Develop high quality innovative solution by: \\
$\checkmark$ encouraging incrementalism \\
$\checkmark$ setting in place stopping criteria \\
$\checkmark$ testing robustness or proposed solutions \\
$\checkmark$ maximising compatibility with existing norms and values of \\
$\quad$ the buyer \\
$\checkmark$ minimising the need for new skills and knowledge \\
$\checkmark$ making outcome / results of innovation visible to user \\
$\checkmark$ enabling potential adopters to experiment before investing \\
\end{tabular}
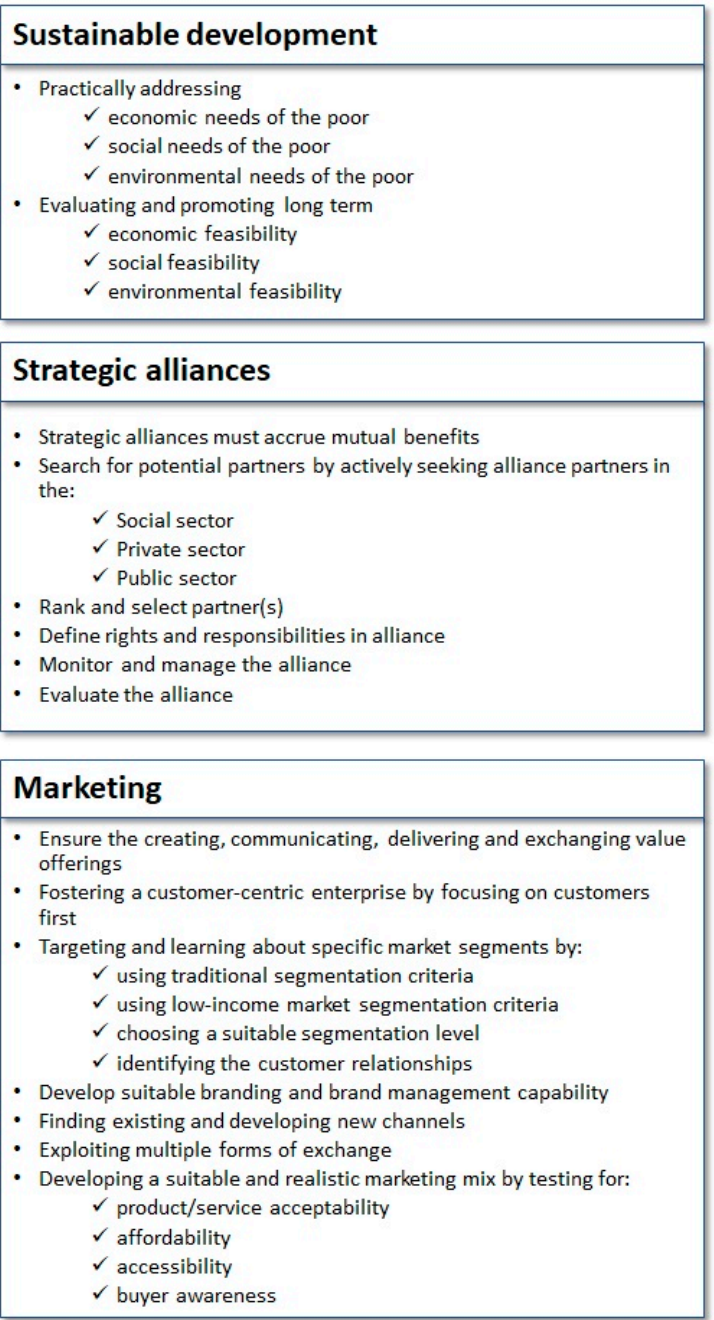

Figure 5. A framework for sustained profitable growth for SMMEs operating at the BoP.

The framework integrates all the aspects that are deemed important to enterprise growth, based on the literature reviewed.

\section{Framework Evaluation (Part 2)}

As described in Section 2.2 the framework was validated by means of semi-structured interviews and an industry survey. The following sections outline the findings from these validation activities.

\subsection{Interviews}

Five industry experts were engaged in semi-structured interviews to test the framework. After introducing the framework, the answers to specific questions were recorded and coded. The main results are summarized in Table 3, which provides the question in the context of the framework and summarizes the respective answers. 
Table 3. Semi-structured interview outcomes.

\begin{tabular}{|c|c|}
\hline Question and Aim & Answer Summary \\
\hline $\begin{array}{l}\text { Are the identified core focus } \\
\text { areas needed for } \\
\text { sustained growth? }\end{array}$ & $\begin{array}{l}\text { The interviewees unanimously agreed that each of the specified } \\
\text { managerial core focus areas are necessary for attaining sustained high } \\
\text { growth at the BoP, including sustainable development; the latter is not a } \\
\text { high growth factor per se, but was deemed necessary for lasting } \\
\text { improvements to the BoP. }\end{array}$ \\
\hline $\begin{array}{l}\text { Does the framework clearly } \\
\text { identify all BoP concerns? }\end{array}$ & $\begin{array}{l}\text { All concerns are well indicated, though the framework should include } \\
\text { more background on the worldviews and cultural characteristics of the } \\
\text { BoP market. }\end{array}$ \\
\hline $\begin{array}{l}\text { Are the essential features of a } \\
\text { framework exhibited? }\end{array}$ & Every one of the essential features of a framework are incorporated. \\
\hline $\begin{array}{l}\text { Does the framework have the } \\
\text { ability to aid in the attainment } \\
\text { of growth? }\end{array}$ & $\begin{array}{l}\text { The interviewees all believe that the framework, if correctly } \\
\text { implemented, will aid SMME owners and/or managers in attaining } \\
\text { higher enterprise growth when targeting the BoP market. Strengths } \\
\text { include that it teaches people a new language, the literature base is } \\
\text { strong, and it provides a clear process to follow. Complexity was seen as } \\
\text { a possible stumbling block requiring possible practical guidance by a } \\
\text { consultant/practitioner. }\end{array}$ \\
\hline $\begin{array}{l}\text { Identifying potential framework } \\
\text { improvement areas }\end{array}$ & $\begin{array}{l}\text { A sharp criticism was that the average SMME owner would find it } \\
\text { difficult to implement such a detailed framework, and that each } \\
\text { enterprise that targets the BoP would struggle to incorporate each } \\
\text { consideration in their endeavors. However, the framework is "as good as } \\
\text { it gets" as its level of detail "can make all the difference". }\end{array}$ \\
\hline $\begin{array}{l}\text { Assessing systemic desirability } \\
\text { and cultural feasibility }\end{array}$ & $\begin{array}{c}\text { The cultural feasibility of the framework was deemed both systemically } \\
\text { desirable and culturally feasible. However, participants clarified that the } \\
\text { framework is indeed only suitable for upper-tier entrepreneurs who } \\
\text { wanted to enter the BoP. Further, even with some education regarding } \\
\text { the framework, they will "need a disciplined, structured approach to go } \\
\text { through it." }\end{array}$ \\
\hline $\begin{array}{l}\text { Assessing systems' } \\
\text { performance measures }\end{array}$ & $\begin{array}{c}\text { All the interviewees agreed that the framework should perform well, } \\
\text { being efficable, efficient, effective, and ethical. }\end{array}$ \\
\hline $\begin{array}{l}\text { Is a feasible evaluation process } \\
\text { incorporated in the framework? }\end{array}$ & $\begin{array}{c}\text { The framework incorporates a feasible evaluation process for owners } \\
\text { and/or managers, but should include a scale to help them to ascertain } \\
\text { where their problem area lies. }\end{array}$ \\
\hline $\begin{array}{l}\text { Would the experts be willing to } \\
\text { hypothetically help implement } \\
\text { the framework? }\end{array}$ & $\begin{array}{l}\text { All of the validators claimed that they would indeed be prepared to } \\
\text { implement the framework in a BoP targeting enterprise under their } \\
\text { control; a few of the experts commented that, to the best of their } \\
\text { knowledge, there is no existing framework with as detailed a process for } \\
\text { appropriately targeting the BoP. }\end{array}$ \\
\hline $\begin{array}{l}\text { What other aspects are important } \\
\text { for implementing the } \\
\text { framework? }\end{array}$ & $\begin{array}{l}\text { The biggest concern was the importance of training the potential users, } \\
\text { as SMME owners are "busy fighting fires all day," so that a detailed } \\
\text { framework such as this would require the involvement of consultants. }\end{array}$ \\
\hline
\end{tabular}

Overall, each of the validation questions was answered positively, and validated the core system components of the framework.

\subsection{Survey Analysis}

\subsubsection{Sample Description}

After the conceptual framework was improved, based on the specific concerns of the experts, a survey was conducted of social entrepreneurs in South Africa, who specifically focused on improving the lot of the BoP. In total, 57 valid responses were received. The sample consisted of micro enterprises. The respondents were classified according to the industry in which they operate, from primary to tertiary, and by a category for their present growth rate. As illustrated in, and as per standard industry classification (SIC), a growth category could not be obtained for two of the respondents, as they were 
only founded in the present year, while the businesses of three of the respondents grew at more than double the inflation rate.

\subsubsection{Frequency Analysis}

In the sections that follow, summary graphs of respondent feedback are provided for each of the framework factors (See Appendix A). The first two graphs show the growth impact and managerial difficulty of the factor, as reported by respondents. Two additional graphs summarize the core framework focus areas of each factor, as outlined in Section 3.2.

As shown in Figure A1 in Appendix A, respondents seem to fall into two extremes in terms of the growth impact of the business model factor. Eleven respondents $(19 \%)$ indicated that they have not addressed this issue at all, while the majority (35 respondents or $61 \%$ ) believe that this factor is important with a consistent positive growth impact on the SMME. Even while saying that it clearly has a positive growth impact, 30 respondents or 53\% indicated that they find implementing and using business modelling tools as either difficult or complex to manage. If one were to exclude the respondents who had not yet addressed the factor, this proportion increases to $64 \%$.

In slight contrast to the impact of addressing aspects pertaining to the business model, more than $70 \%$ of respondents believe that business modelling is an important element of planning. They place a lot of emphasis on understanding and determining their key resources for their chosen business model, and on establishing or estimating the relevant revenue streams. However, when considering the manner of implementation, there seems to be less emphasis in customer segmentation or defining channels to the customer-an aspect that is clearly required for estimating revenue streams. It is also clear that most companies consider participating in the BoP market "on their own", as is shown by the low importance attached to identifying any partners: Less than $30 \%$ of respondents attached importance and urgency to planning for this aspect, while only slightly more than $20 \%$ address this directly during implementation.

As far as sustainable development impact is concerned (See Figure A2 in Appendix A), less than half of the respondents believe that there is either a consistent positive impact, or at least that benefits outweigh costs; $32 \%$ believe the impact is negligible; and $10.5 \%$ state that the impact is negative. Some of the comments seem to indicate that this might be a phenomenon that emerges in developing countries, where less emphasis is generally placed on sustainability and more focus is placed on economic and social needs. Although most respondents highlighted environmental factors, these clearly remain secondary to the needs of the BoP.

As far as strategy is concerned, there is a strong consensus that it has a strong positive impact on growth, but that it is at the same time difficult and even complex to manage. It is vital that a clear strategy is documented for both planning and implementation and compiled through direct interaction with potential customers by getting into the field. The strong focus on economic needs is also reflected in the priority of planning at a strategic level, where factors such as affordability, accessibility, and acceptability of solutions are important. There is thus a strong positive correlation in the results between Figures A3 and A4 (Appendix A) with respect to addressing economic needs of the target audiences of SMMEs and affordability.

Even though a large majority (67\%) of respondents believe that innovation plays an important part and contributes towards growth, quite a few believe that innovation is actually quite easy to manage when compared to strategy. The most important aspect here is active grassroots engagement, with a clear indication that one should not experiment, but should focus on a fully tested innovation before adoption. This in all probability is addressing the perception of customers at the BoP that they are being experimented with or even exploited. This goes hand in hand with many respondents stressing the need for involving the community.

Creating innovative solutions to either develop new ideas or improve existing offerings is regarded as having a high positive impact, but is extremely difficult, or even complex, to manage. The authors believe that this seeming complexity is the result thereof that not many companies have a sustained 
high growth in this market, as it is a relatively new approach with little experience or help from consultants' models or frameworks to facilitate a successful implementation. As before, the consensus that solutions have to be affordable, customer centric, and acceptable within the community are highlighted as important, and must be addressed at least implicitly. There is also consensus that branding, which is so vital at high income levels, seems to be less important here.

Strategic alliances are considered as important and as having a positive impact by $65 \%$ of respondents, even though identifying key partnerships had the lowest priority in business modelling. One reason could be that this is regarded as a more operational problem that can potentially be addressed during implementation. This is also in line with the findings associated with Figure A6 in Appendix A, where most companies seem to be entering the market on their own, at least originally. As far as planning for Strategic alliances is concerned, BoP entrepreneurs prioritize the development of alliances, but mostly seek private sector partnerships. It thus becomes vital for Government to take cognizance of this when seeking to establish public-private partnerships to encourage economic growth. There is also again a strong emphasis on economic drivers, including minimizing transaction costs. One contra-indicator is the fact that relatively little emphasis is placed on co-creation, and/or addressing cultural differences. However, this aspect was highlighted under strategy, where it was to be developed through grass roots involvement and engagement. Even so, the extent to which these SMMEs are truly engaging with grassroots actors and have truly inclusive practices seems to be limited.

\subsubsection{Reliability and Validity}

The reliability and validity of the survey questionnaire was tested with the Cronbach reliability test, where alpha is a measure of internal consistency - that is, how closely related a group of items is. This is considered to be a measure of scale reliability. The alpha values for each of the constructs and sub-constructs are shown in Table 4; the comments include particular concerns that would raise the alpha value meaningfully if omitted from the survey (and therefore the framework).

Table 4. Construct and sub-construct reliabilities.

\begin{tabular}{|c|c|c|}
\hline Construct & $\alpha$ & Alpha Improvement If Component Is Deleted \\
\hline Perceived growth impact & 0.744 & No improving moves \\
\hline Managerial difficulty & 0.815 & No improving moves \\
\hline Priority level in planning & 0.97460 & $\begin{array}{l}\text { Practically addressing environmental needs of the poor } \\
\qquad(+0.00012) \\
\text { Addressing key organizational hurdles for optimal strategy } \\
\text { implementation }(+0.00006)\end{array}$ \\
\hline Sub-Construct & $\alpha$ & Alpha Improvement If Component Is Deleted \\
\hline Business modelling component & 0.825 & Estimating revenue streams $(+0.003)$ \\
\hline Sustainable development component & 0.794 & No improving moves \\
\hline Business strategy component & 0.858 & Addressing key organizational hurdles $(+0.002)$ \\
\hline Strategic alliance component & 0.954 & No improving moves \\
\hline Innovation component & 0.934 & No improving moves \\
\hline Marketing component & 0.900 & No improving moves \\
\hline Manner of implementation & 0.976 & No improving moves \\
\hline Business modelling component & 0.837 & No improving moves \\
\hline Sustainable development component & 0.762 & Practically addressing social needs of the poor $(+0.021)$ \\
\hline Business strategy component & 0.856 & Addressing key organizational hurdles $(+0.002)$ \\
\hline Strategic alliance component & 0.954 & No improving moves \\
\hline Innovation component & 0.938 & No improving moves \\
\hline Marketing component & 0.896 & No improving moves \\
\hline
\end{tabular}

Given the satisfactory alpha values, no changes were required to increase reliability. This implies that the requirements of the framework are reliable, in that they exhibit internal consistency (interconnectedness) and homogeneity (uni-dimensionality). 


\subsubsection{Variance Analyses}

The components of a box and whisker plot in Figure 6 indicate the manner by which the figures in the remainder of the article outline the means and confidence intervals for the growth rates of each growth factor, for each of the survey question categories.

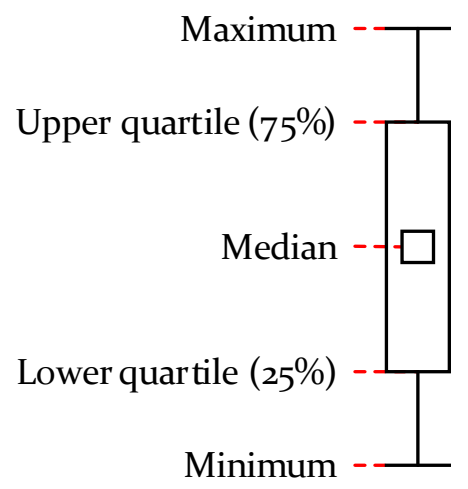

Figure 6. Histogram and confidence interval components.

When rating the perceived growth impact of each factor, Figure 7 clearly indicates that the high-growth respondents rate the impact consistently higher for all factors, except for marketing, where almost everyone agreed that it has a positive impact.

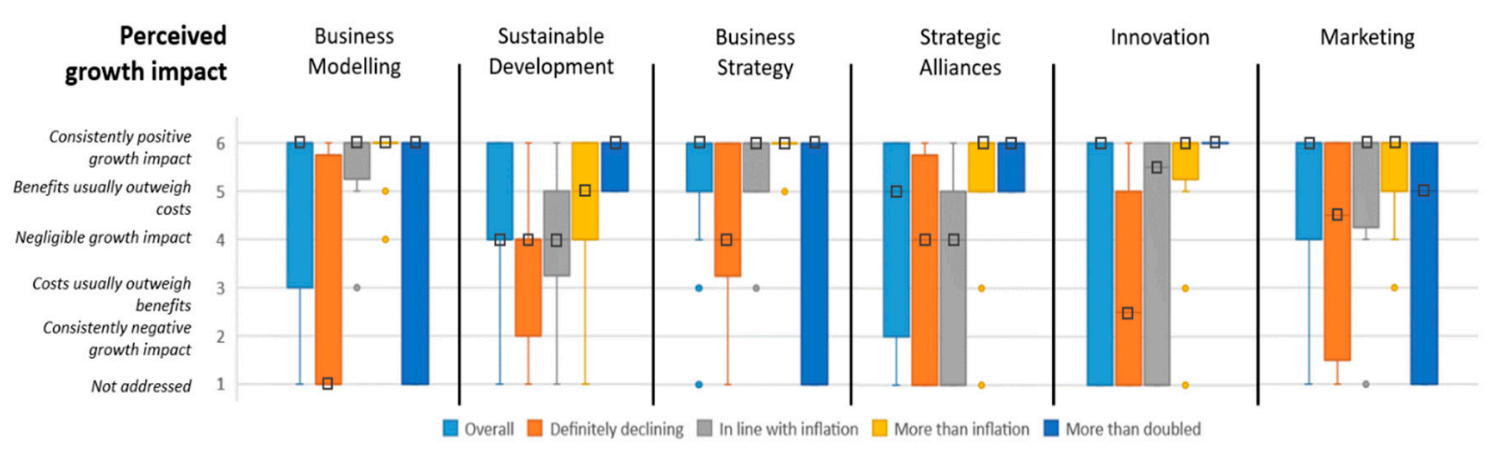

Figure 7. Perceived growth impact according to growth factor and growth rate.

Figure 8 shows the response summary for the question pertaining to managerial difficulty, which indicates how difficult each growth factor is to manage. It appears that, as enterprises grow, the difficulty of managing the growth factors increases, though only up to a point. It is hypothesized that, in moving from declining to positive growth, respondents tend to see the underlying complexities of each of the growth factors; once they have dealt with them, the processes become natural and engrained in the enterprises, leading to a decrease in their managerial difficulty. Interestingly, failing enterprises show a decidedly lower perception of managerial difficulty, which likely indicates a low regard for a structured approach to growth. It appears that the perceived difficulty is a necessary precursor to positive growth attainment, whereas viewing it too simplistically may lead to trivializing its importance and thus inhibiting advancement. 


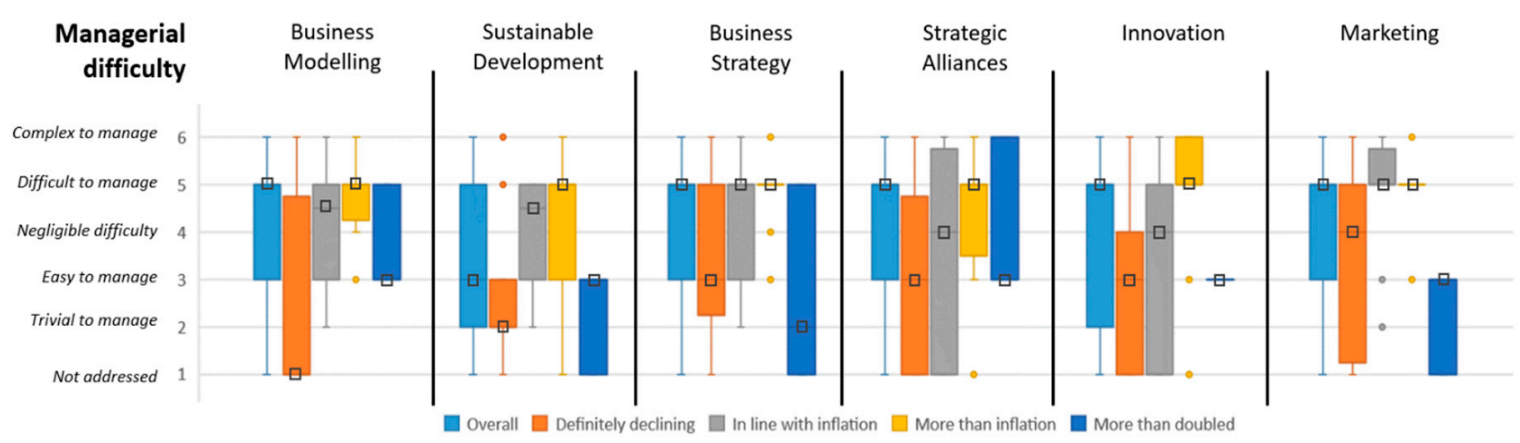

Figure 8. Managerial difficulty according to growth factor and growth rate.

Figure 9 shows respondents' priority level in managing of each growth factor. Ideally, the priority level is listed as important (regardless of urgency) for orientating the enterprise for growth, in accordance with the framework requirements. It must be noted that the results shown here are dependent on multiple framework requirements, whereas the two preceding figures only address the highest order growth factors, and not their sub-requirements.

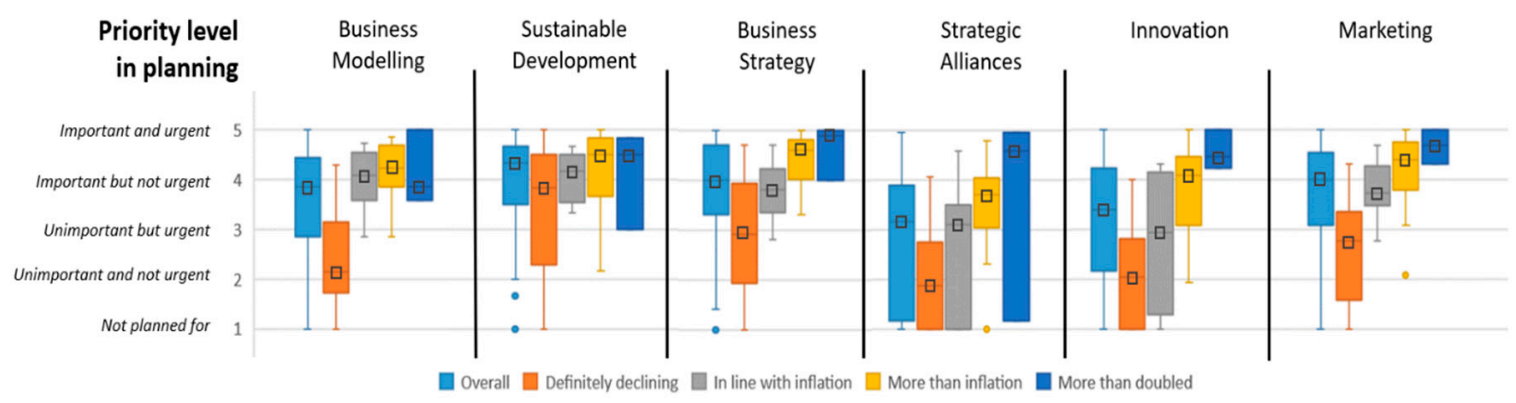

Figure 9. Priority level in planning according to growth factor and growth rate.

Respondents with higher growth rates regard the growth factors as increasingly important to plan for. The necessity of planning for business modelling and sustainable development seems to be generally well accepted across the range of enterprises with different growth rates. However, planning for innovation, marketing, and strategic alliances seem to exhibit very clear differences between the growth categories, with more successful enterprises viewing planning for these as much more important and urgent.

Figure 10 outlines the results of a detailed analysis of numerous requirements for each growth factor, detailing the manner in which each is implemented by the respondents. Ideally, the sub-requirements are addressed directly/explicitly to best position the enterprise for growth, in accordance with the framework requirements.

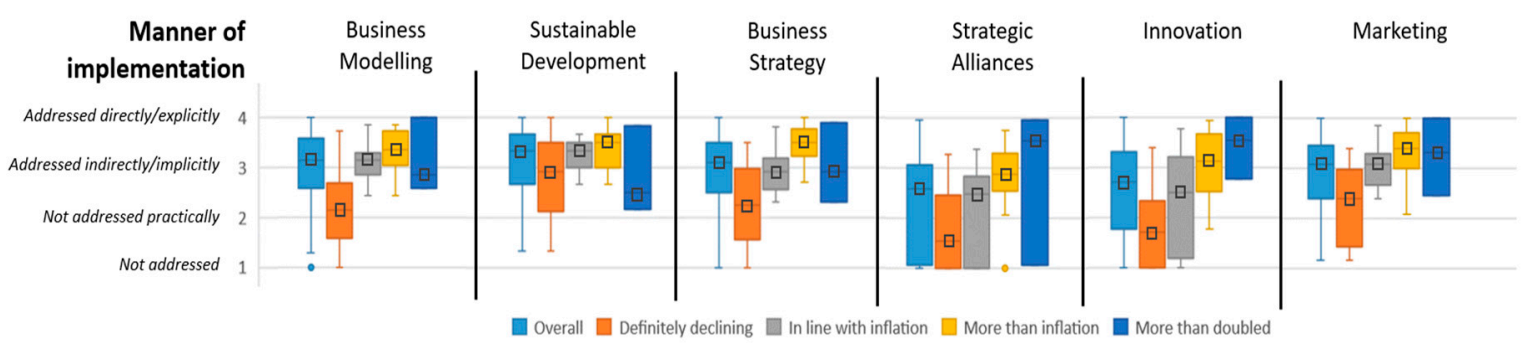

Figure 10. Manner of implementation according to growth factor and growth rate. 
A general increasing trend is depicted above, showing that higher-growth enterprises tend to address the requirements of the growth factors more directly and explicitly, in comparison to their less successful counterparts. It is possible that, as business strategy becomes engrained in the operations of successful enterprises, it becomes a less pressing concern that is addressed implicitly, accounting for the lower mean of the highest growth rate enterprises.

\section{Conclusions}

A key challenge faced by South African enterprises operating at the Base of the Pyramid is the difficulty of achieving sustained profitable growth whilst simultaneously promoting sustainable poverty alleviation. This study developed a framework of growth promoting factors to provide consultants, enterprise owners, and academics alike with a means by which to guide Small, Medium, and Micro-sized Enterprises (SMMEs) operating in the BoP towards attaining higher, lasting growth and socio-economic development. Existing enterprise growth models and frameworks have been found wanting in terms of their ability to cater for the unique approach necessary for navigating through the adverse and atypical conditions prevalent at the BoP.

A systematic literature review identified 25 antecedents to enterprise growth (or growth factors), of which five were within this study's scope in that they are business strategy related and within direct control of the enterprise. These are: Business modelling for detailed planning; following a suitable and detailed business strategy for long-term growth; utilizing innovation to consistently create value and respond rapidly to market changes; implementing good marketing practices to ensure maximum value delivery to customers; and forming strategic alliances to bolster core competencies, leverage resources, and scale operations. Furthermore, pursuing sustainable development was determined as crucial to ensuring both lasting profitability and social impact is realized.

The framework was iteratively developed by synthesizing the BoP requirements with conventional growth factor processes, verifying the preliminary framework, and incorporating validation findings in its final design. Framework validation included a survey of 57 for-profit South African enterprises to empirically establish need, reliability, relevance, and usefulness, and; expert focus interviews to maximize usability by identifying key stakeholder requirements within the framework.

Table 5 summarizes the growth factors, with the empirically developed relative ranking of dimensions, as well as the policy insights derived from each factor. The table shows the dimensions, relative ranking of the concepts, and the SMME management insights that follow from the priority afforded to the elements and their extent of implementation. The aim with this table is to highlight possible weaker areas in managing SMMEs to achieve high growth. The authors acknowledge that each SMME is faced by challenges specific to its context, and it is in this respect that the framework may aid in highlighting good practices that could be explored, depending on the challenges faced and the phase of the SMME's growth path. It provides high-level dimensions and the best practices associated with them and serves as a guideline towards growth.

The unique contribution of this work is embodied in: The framework's novelty, combining multiple fields of knowledge pertaining to success at the BoP and in traditional markets into a cohesive whole for the first time; the confirmed practical significance of the framework requirements in that it provides users with an empirically vetted procedure for increasing growth potential as evidenced by the survey data; and the optimized usability due to the visually clear framework, and incorporation of key focus areas for dealing with key stakeholders.

The limitations of the study point towards the following areas of future research:

Increasing depth of survey analysis: The validation process survey holds valuable information that is sufficiently useful for the purposes of this study. However, with respect to its ability to accurately determine key differences across sectors, it falls short due to its small sample size of 57 . This promotes the need for a much bigger survey to be conducted on social enterprises wherein at least 30 samples are obtained per sector for researchers to perform a cross-sectoral analysis, which would add more value to the framework in terms of its ability to deduce key requirements particular to each sector when 
dealing with key stakeholders. Furthermore, it is not easy to measure the impact social enterprises are making in their ecosystems, but including this information in a future empirical analysis could add valuable insight into whether those enterprises with the highest growth rates are doing the most good, or if there is some degree of exploitation occurring.

Empirical testing: The framework's subsystems could be tested by real life application (i.e., validation by implementation), and thereafter refined via a thorough empirically backed investigation into the impact that the application of the framework has on the social enterprise.

Improving usability: To make the framework more user-friendly for SMME owners with little time on their hands and less familiarity with the concepts contained in the framework and its subsystems, a usable interface could be developed to make the framework accessible to users other than consultants. 
Table 5. Policy insights from each dimension.

\begin{tabular}{|c|c|c|}
\hline Dimensions & Relative Ranking of Concepts & Policy Insights: What Are Good Practices for Others to Learn From? \\
\hline Business model & $\begin{array}{l}\text { Higher level of priority and implementation } \\
\text { - } \quad \text { Business modelling [BM1] } \\
\text { - } \quad \text { Estimating revenue streams [BM6] } \\
\text { - } \quad \text { Determining key resources [BM7] } \\
\text { Lower level of priority and implementation } \\
\text { - } \quad \text { Defining channels [BM3] } \\
\text { - } \quad \text { Customer relationships [BM4] } \\
\text { - } \quad \text { Identifying key partnerships [BM8] }\end{array}$ & $\begin{array}{l}\text { - In SMMEs where poor growth has been experienced, a significant } \\
\text { number of owners have not explicitly addressed business modelling } \\
\text { BMs are regarded as difficult to manage by those who did not } \\
\text { implement them } \\
\text { - Accessing the BoP without suitable partners seems to take place quite } \\
\text { often; while this may lead to lower-than-expected results, the latter } \\
\text { may have a large variance, given its complexity } \\
\text { - SMME owners need to be explicit in their consideration of } \\
\text { relationships with customers and the channels to reach them }\end{array}$ \\
\hline Sustainable Development & $\begin{array}{l}\text { Higher level of priority and implementation } \\
\text { - } \quad \text { Economic needs [SD1] } \\
\text { - } \quad \text { Social needs [SD2] } \\
\text { - } \quad \text { Social feasibility of business plan [SD5] } \\
\text { - } \quad \text { Environmental feasibility of business plan [SD6] } \\
\text { Lower level of priority and implementation } \\
\text { - } \quad \text { Environmental needs [SD3] } \\
\text { - } \quad \text { Economic feasibility of business plan [SD4] }\end{array}$ & $\begin{array}{l}\text { - Social needs are considered as of a higher priority than the level } \\
\text { of implementation } \\
\text { - The economic feasibility of the business plan seems to be given } \\
\text { less thought } \\
\text { - This may be indicative of the tension between social and } \\
\text { economic missions } \\
\text { - Environmental feasibility is generally neglected }\end{array}$ \\
\hline Strategy & \begin{tabular}{ll}
\multicolumn{2}{l}{ Higher level of priority and implementation } \\
- & Documenting a clear strategy [S1] \\
- & Addressing key hurdles [S2] \\
- & Getting into the field [S4] \\
- & Maximizing buyer acceptability [S6] \\
- & Affordability [S7] \\
- & Accessibility [S8] \\
- & Awareness [S9] \\
Lower level of priority and implementation \\
- & Strategic profile [S2] \\
- & Determining competitive factors [S4]
\end{tabular} & $\begin{array}{l}\text { - Strategy is the activity that is best planned for, and most respondents } \\
\text { agree that it has a big impact on growth } \\
\text { - Issues related to economic feasibility ranks highly, especially in terms } \\
\text { of accessing the BoP } \\
\text { - Issues that are externally focused (other than target markets), such as } \\
\text { considering competitive factors, are less focused on } \\
\text { - Success requires that good partnerships need to be formed - trust is } \\
\text { very important and minimizes the costs of engagement }\end{array}$ \\
\hline
\end{tabular}


Table 5. Cont.

\begin{tabular}{|c|c|c|}
\hline Dimensions & Relative Ranking of Concepts & Policy Insights: What Are Good Practices for Others to Learn From? \\
\hline $\begin{array}{l}\text { Strategic Alliances } \\
\text { Marketing }\end{array}$ & $\begin{array}{ll}\text { Higher level of priority and implementation } \\
\text { - } & \text { Seeking alliance in private sector SA2 } \\
\text { - } & \text { Promote trust SA13 } \\
\text { Lower level of priority and implementation } \\
\text { - } \quad \text { Seeking alliance in social sector [SA2] } \\
\text { - } \quad \text { Seeking alliance in public sector [SA4] } \\
\text { - } \quad \text { Evaluating suitability of partner [SA5] } \\
\text { - } \quad \text { Contracting [SA6] } \\
\text { - } \quad \text { Create engagement spaces [SA7] } \\
\text { - } \quad \text { Gain access to knowledge SA9 } \\
\text { - } & \text { Co-creation [SA10] } \\
\text { - } & \text { Managing IP [SA11] } \\
\text { - } & \text { Mddressing cultural differences [SA12] } \\
\text { - } & \text { Gaininize risk and opportunistic behavior [SA13] } \\
\text { - } & \text { Enhancing relationship building [SA16] } \\
\text { - } & \text { Safeguarding key competences [SA17] } \\
\text { - } & \text { Minimize transaction costs [SA18] } \\
- & \text { Evaluating the alliance [SA19] }\end{array}$ & $\begin{array}{l}\text { - In line with the low priority afforded to partners (see the business } \\
\text { modelling section), strategic alliances is the growth factor that } \\
\text { SMMEs give less attention to; } \\
\text { - The platform and engagement function is relatively neglected due to } \\
\text { the low priority of strategic alliances } \\
\text { - Private sector alliances are slightly preferred over public } \\
\text { - } \quad \text { Evector alliances } \\
\text { - Managion of alliances is very poorly addressed }\end{array}$ \\
\hline Marketing & $\begin{array}{ll}\text { Higher level of priority and implementation } \\
\text { - } & \text { Customer-centricity [M1] } \\
\text { - } & \text { Traditional segmentation criteria [M2] } \\
\text { - } & \text { Suitable segmentation level [M4] } \\
\text { - } & \text { Channels for communicating [M7] } \\
\text { - } & \text { Acceptability [M9] } \\
\text { - } & \text { Affordability [M10] } \\
\text { - } & \text { Availability [M11] } \\
\text { - } & \text { Awareness [M12] } \\
\text { Lower level of priority and implementation } \\
\text { - } & \text { Marketing [M1] } \\
\text { - } & \text { BoP market segmentation criteria [M4] } \\
\text { - } & \text { Identifying customer relationships [M6] } \\
\text { - } & \text { Branding [M7] } \\
\text { - } & \text { Multiple forms of exchange [M9] }\end{array}$ & $\begin{array}{l}\text { - Marketing seems to be one of the most planned-for consideration } \\
\text { by SMMEs } \\
\text { Engagement and knowing the BoP segmentation seems to be less } \\
\text { planned for or implemented } \\
\text { Multiple forms of exchange should be exploited, including } \\
\text { structured, networked, pure, and centralized exchanges (e.g., using } \\
\text { standardized processes, social links, trade lefts, and political } \\
\text { influences, respectively) }\end{array}$ \\
\hline
\end{tabular}


Table 5. Cont.

\begin{tabular}{|c|c|c|}
\hline Dimensions & Relative Ranking of Concepts & Policy Insights: What Are Good Practices for Others to Learn From? \\
\hline Innovation & 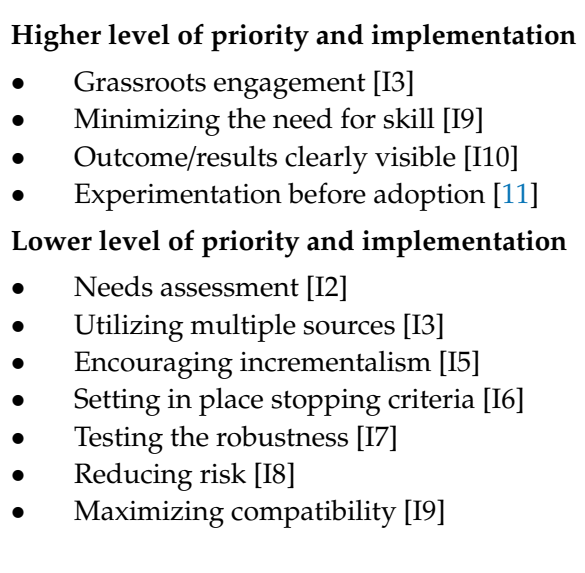 & $\begin{array}{l}\text { - Innovation seems to be prioritized, especially in terms of value to the } \\
\text { target audience (skills, outcomes visible to adopters, and } \\
\text { experimentation with solutions) } \\
\text { - Capturing quality-yet another economic consideration-seems to } \\
\text { be of lower priority; this relates to compatibility with existing norms, } \\
\text { which makes the innovation viable } \\
\text { Engagement and linkages to communities seem to be prioritized, as } \\
\text { there seems to be a large focus on the target market } \\
\text { - The link to economic aspects seems weak, as SMMEs do not } \\
\text { prioritize the implementation of criteria to terminate costly/unfruitful } \\
\text { ideas early on } \\
\text { There is less focus on understanding the market (segmentation) and } \\
\text { facilitating a range of exchange mechanisms, and these may } \\
\text { become misaligned } \\
\text { - Solutions are co-created with the target market to ensure good } \\
\text { products, and to ensure that they do not feel experimented on }\end{array}$ \\
\hline
\end{tabular}


Supplementary Materials: The following are available online at http://www.mdpi.com/2071-1050/12/22/9327/s1, Supplementary A: Survey of best practices in South African social enterprises, Supplementary B: Managerial difficulty Likert-scale options in survey.

Author Contributions: Conceptualization, M.D.v.d.M., S.S.G., C.S.L.S., and K.H.v.L.; methodology, M.D.v.d.M., S.S.G., C.S.L.S., and K.H.v.L.; validation, M.D.v.d.M., S.S.G., C.S.L.S., and K.H.v.L.; formal analysis, M.D.v.d.M.; investigation, M.D.v.d.M.; resources, S.S.G., C.L.S., and K.H.v.L.; data curation, M.D.v.d.M., S.S.G.; writing —original draft preparation, M.D.v.d.M., S.S.G., I.A.M., C.S.L.S., K.H.v.L.; writing一review and editing, S.S.G. and I.A.M.; visualization, M.D.v.d.M.; supervision, S.S.G., C.S.L.S., and K.H.v.L.; project administration, M.D.v.d.M. and S.S.G.; funding acquisition, S.S.G., C.S.L.S., and K.H.v.L. All authors have read and agreed to the published version of the manuscript.

Funding: The APC was funded by DST-NRF Centre of Excellence in Scientometrics and Science, Technology and Innovation Policy (SciSTIP), Stellenbosch University.

Acknowledgments: We thank all respondents to our survey for their invaluable input and insights.

Conflicts of Interest: The authors declare no conflict of interest.

\section{Appendix A}

Table A1. Growth impact and managerial difficulty Likert-scale options in survey.

\begin{tabular}{ll}
\hline Growth Impact Options [GI] (Ranked from 1 to 6) & Managerial Difficulty Options [MD] (Ranked from 1 to 6) \\
\hline 1. We have not addressed this & 1. Not addressed \\
2. Consistently negative growth impact & 2. Trivial to manage \\
3. Costs usually outweigh benefits & 3. Easy to manage \\
4. Negligible growth impact & 4. Negligible difficulty \\
5. Benefits usually outweigh costs & 5. Difficult to manage \\
6. Consistently positive growth impact & 6. Complex to manage \\
\hline
\end{tabular}

Table A2. Priority level in planning and Manner of implementation Likert-scale options in survey.

\begin{tabular}{ll}
\hline Priority Level in Planning (Ranked from 1 to 5) & Manner of Implementation (Ranked from 1 to 4) \\
\hline 1. Not planned for & 1. Not addressed at all \\
2. Unimportant and not urgent & 2. Not addressed practically \\
3. Unimportant but urgent & 3. Addressed indirectly/implicitly \\
4. Important but not urgent & 4. Addressed directly/explicitly \\
5. Important and urgent & \\
\hline
\end{tabular}


Business Model impact

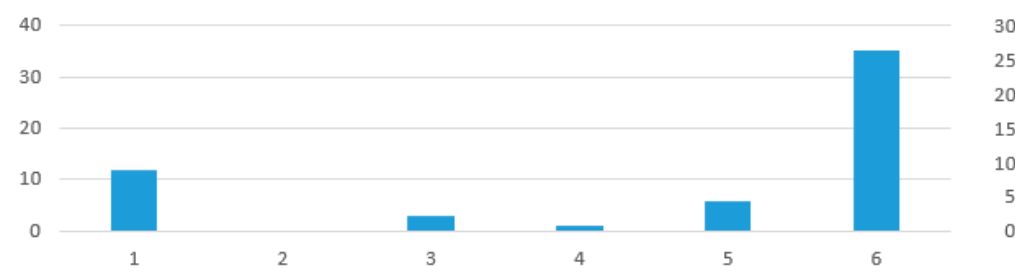

Priority in planning: Business modelling

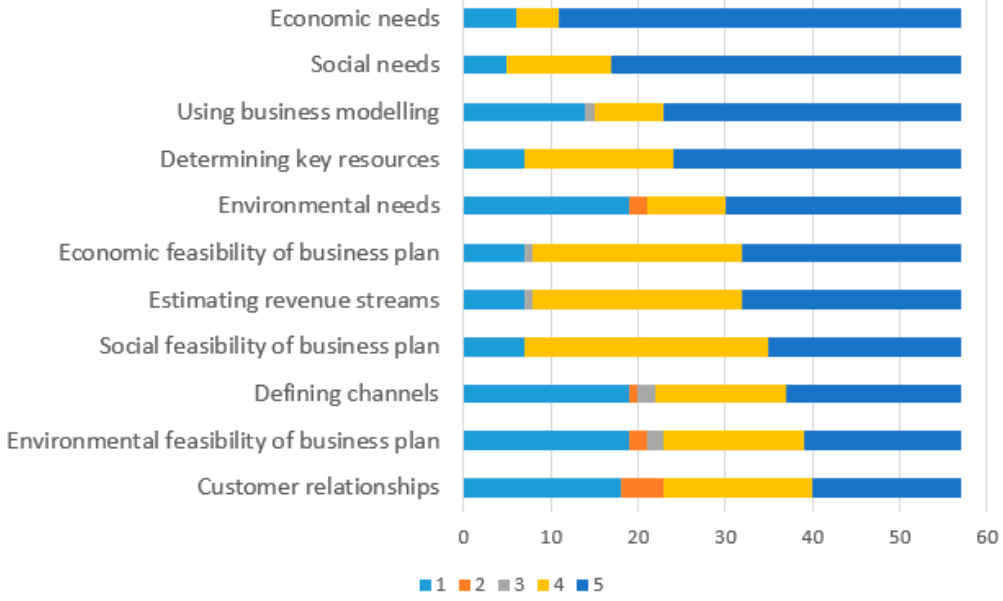

Business Model managerial difficulty

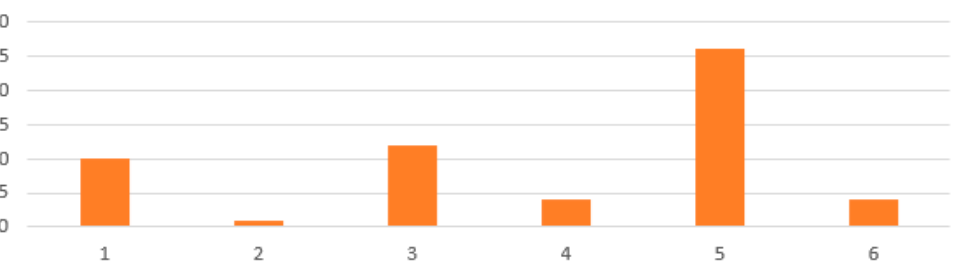

Manner of implementation: Business modelling

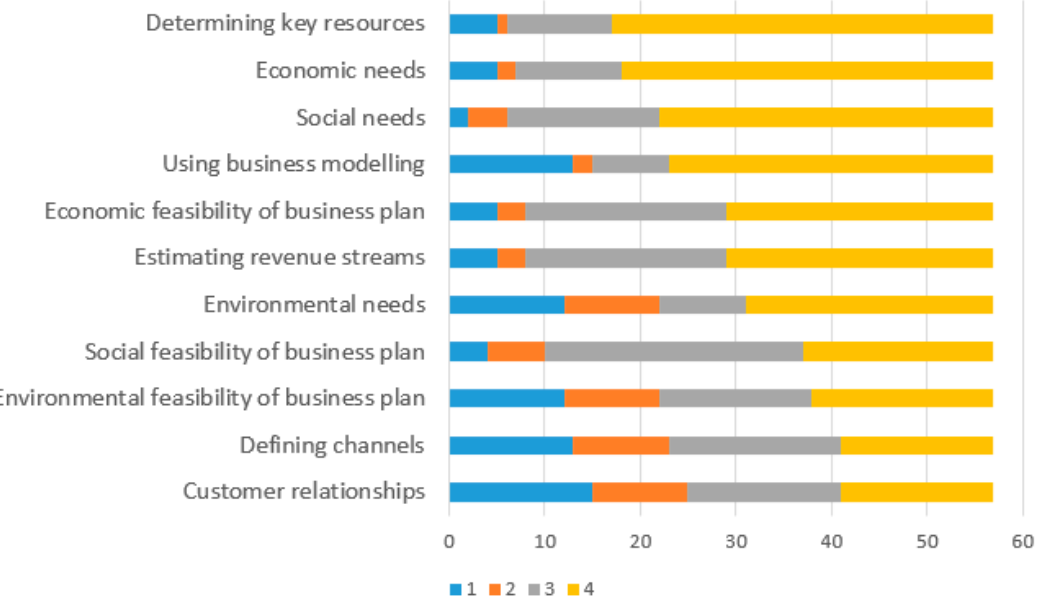

Figure A1. Frequency analysis: Business Model $(\mathrm{N}=57)$. 


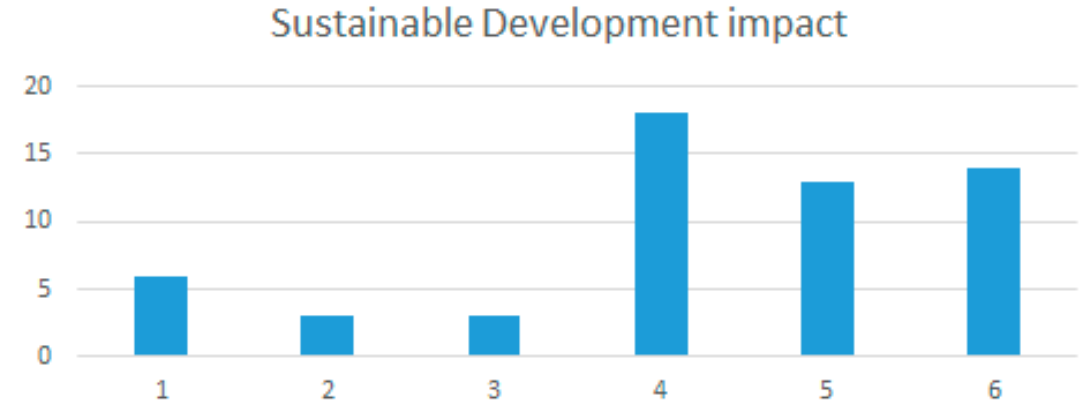

Priority in planning: Sustainable Development

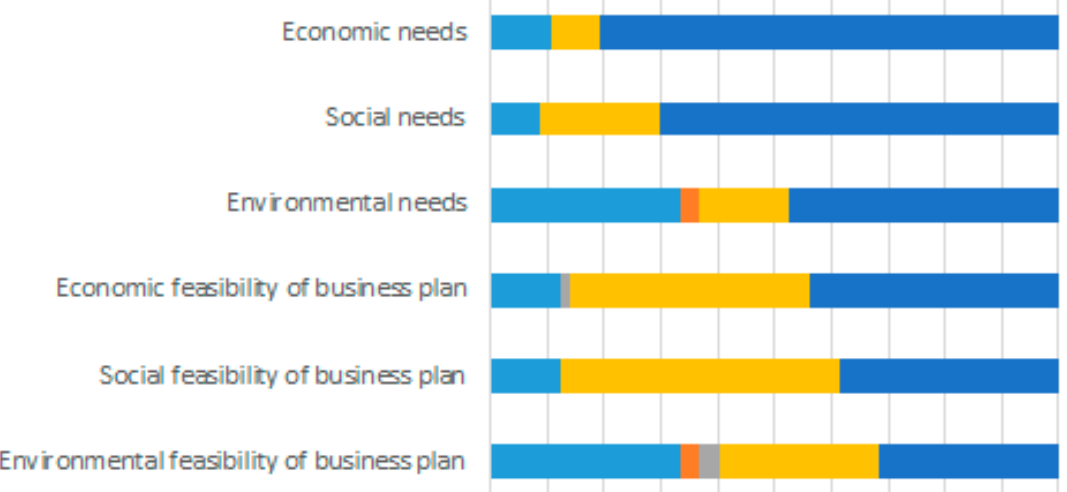

$0 \% 10 \% 20 \% 30 \% 40 \% 50 \%$ 60\% $70 \%$ 80\% $90 \% 100 \%$
Sustainable Development managerial difficulty

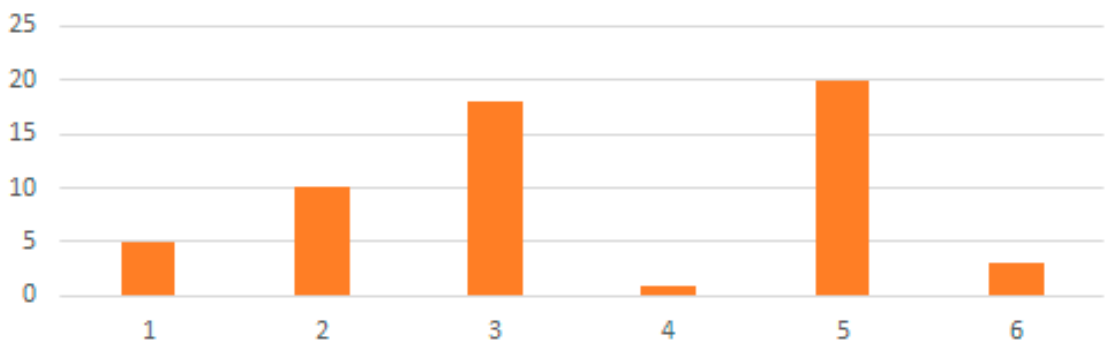

Manner of implementation: Sustainable Development

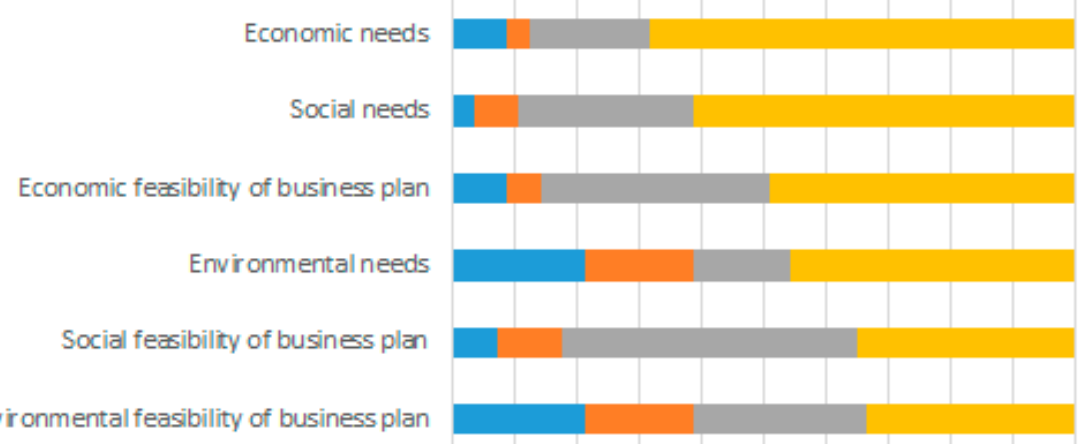

$0 \% \quad 10 \% \quad 20 \% 30 \% \quad 40 \% \quad 50 \% \quad 60 \% \quad 70 \% \quad 80 \% \quad 90 \% 100 \%$ घ 1 = 2 = $3=4$

Figure A2. Frequency analysis: Sustainable Development $(\mathrm{N}=57)$. 


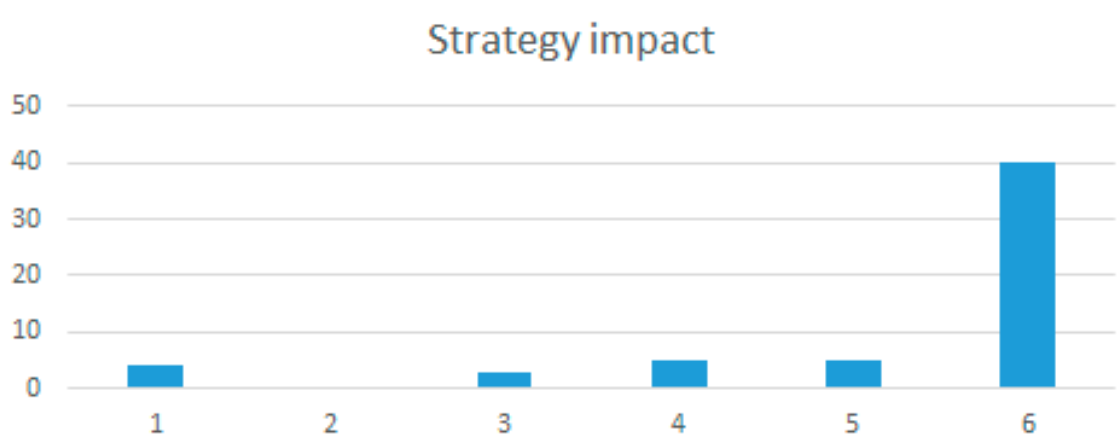

Priority in planning: Strategy

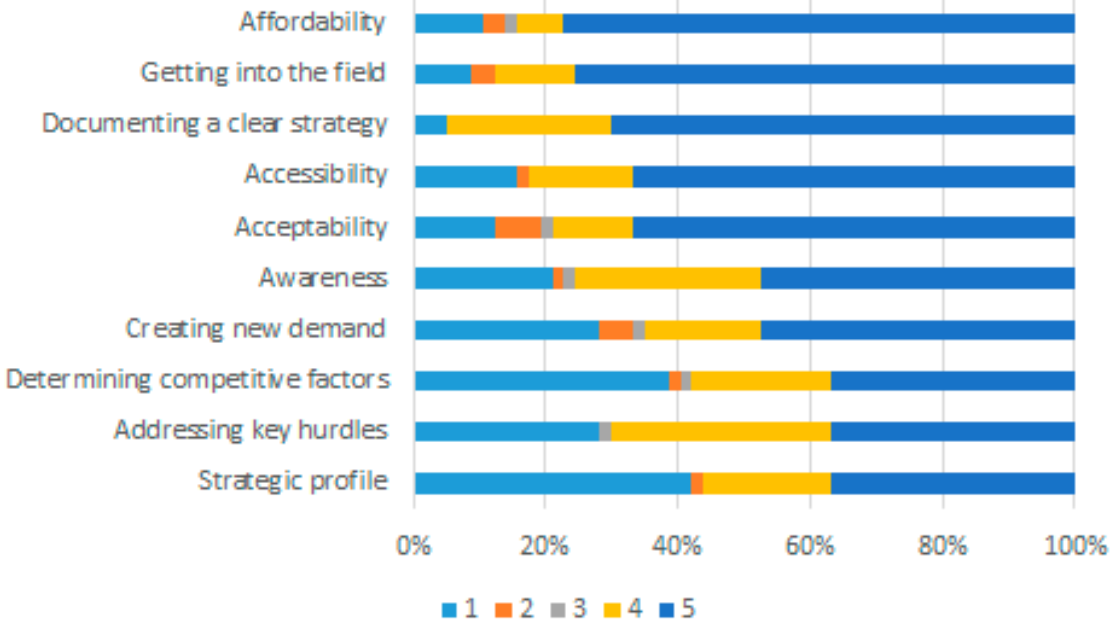

Figure A3. Frequency analysis: Strategy $(\mathrm{N}=57)$
Strategy managerial difficulty

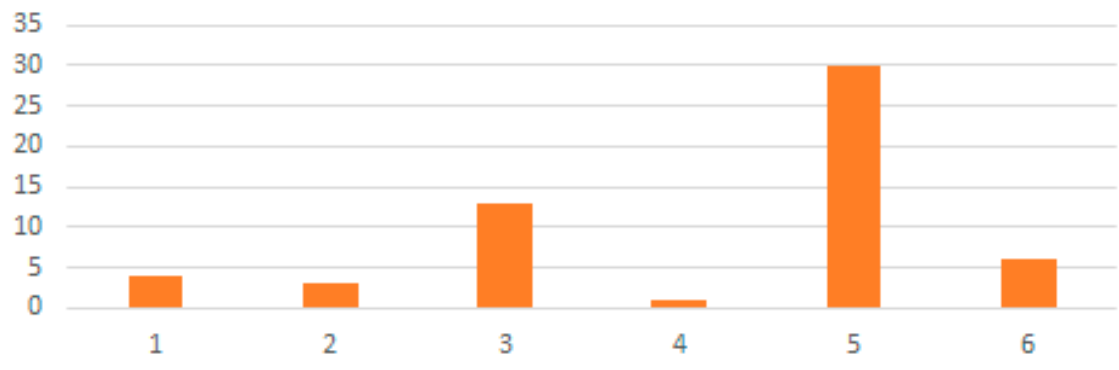

Manner of implementation: Strategy

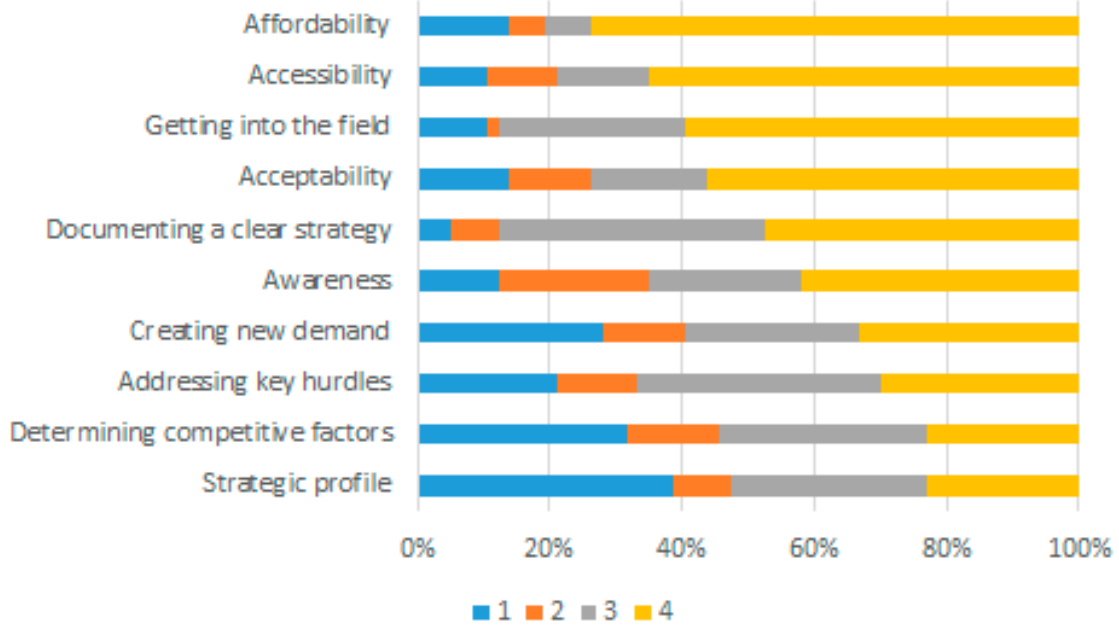

Affordability into the field

$$
\text { Awareness }
$$

Creating new demand

ing key hurdles

Strategic profile

$\square 1=2 \backsim 3=4$ 
Innovation impact

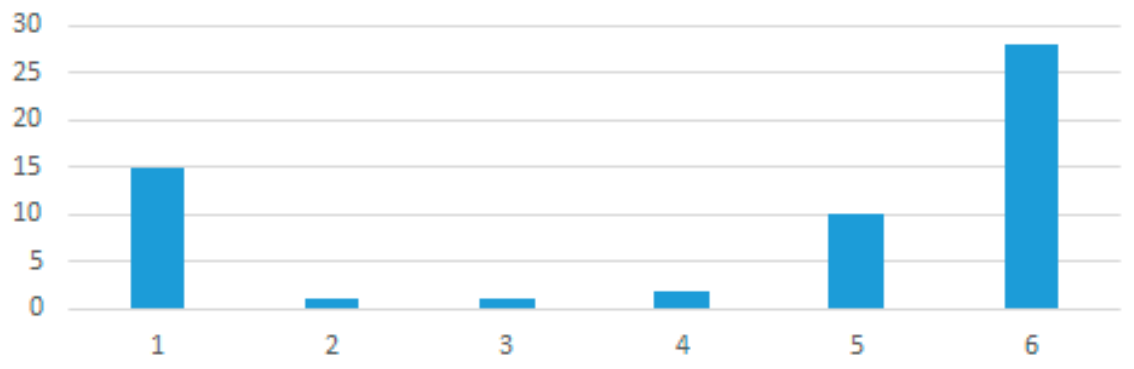

Priority in planning: Innovation

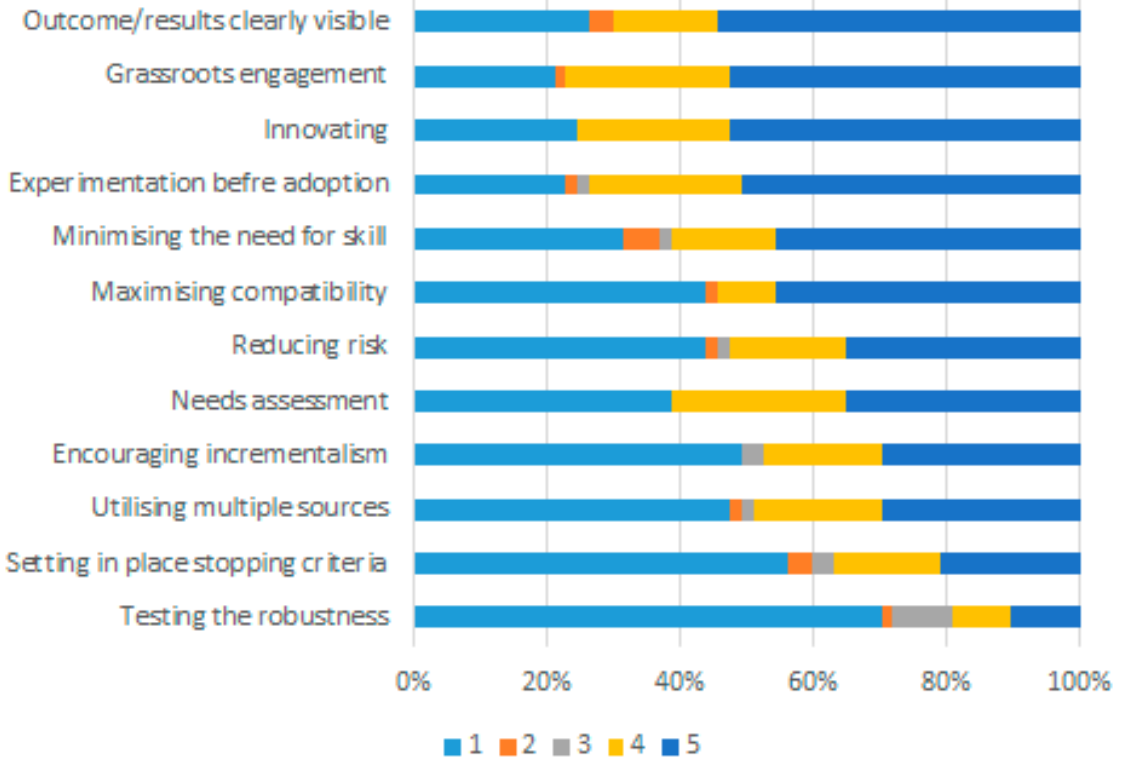

Innovation managerial difficulty

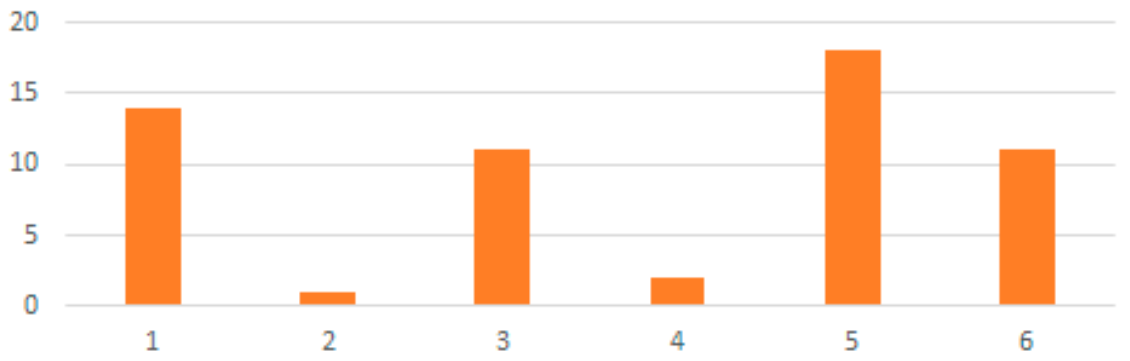

Manner of implementation: Innovation

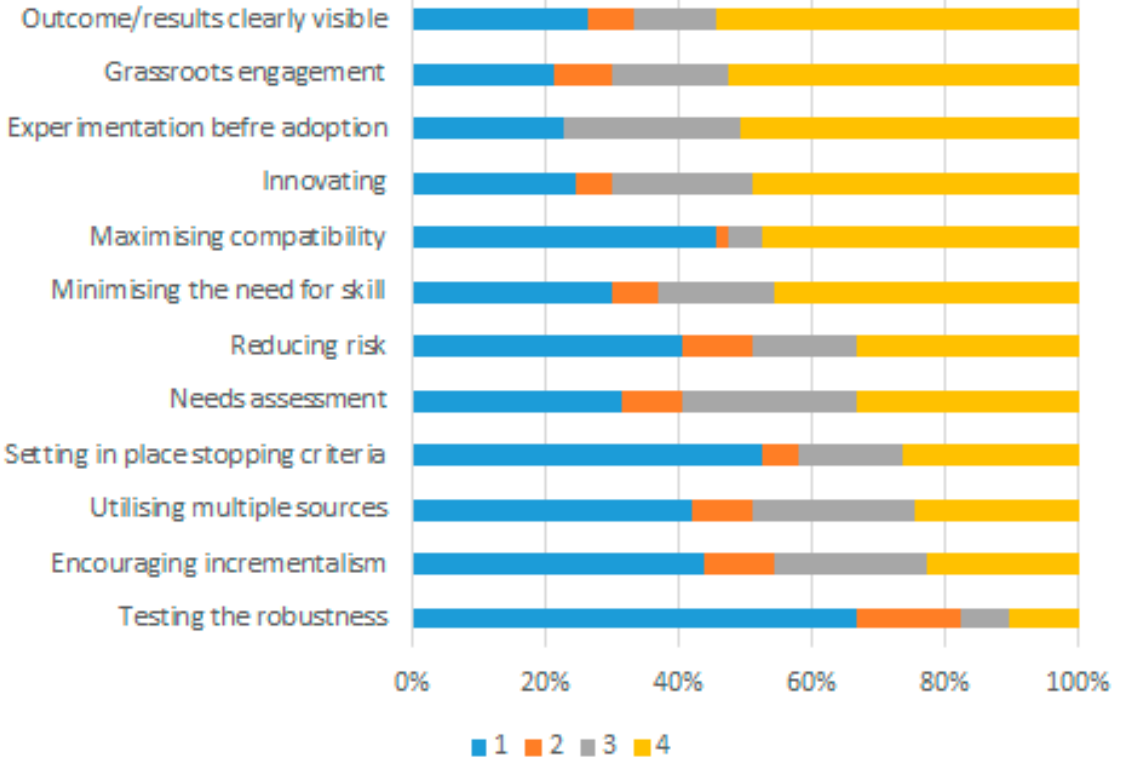

Outcome/results clearly visble Grassroots engagement adoption

Maximising compaibility Reducing ris Testing the robustnes: 1 घ 2 घ 3

Figure A4. Frequency analysis: Innovation $(\mathrm{N}=57)$. 
Marketing impact

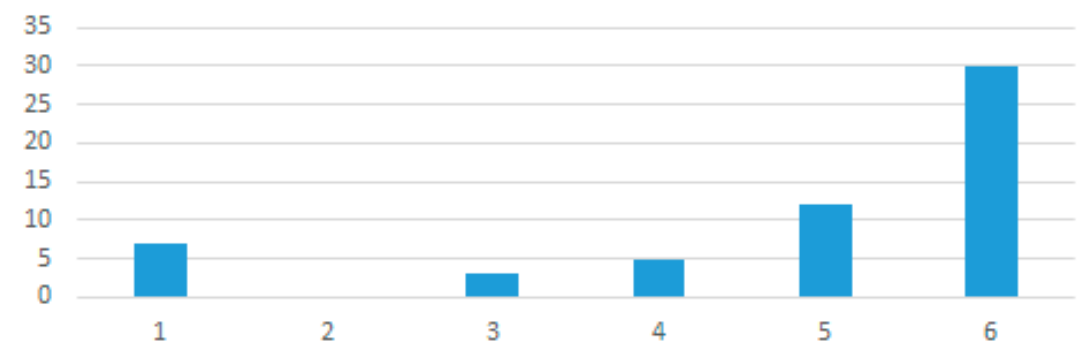

Priority in planning: Marketing

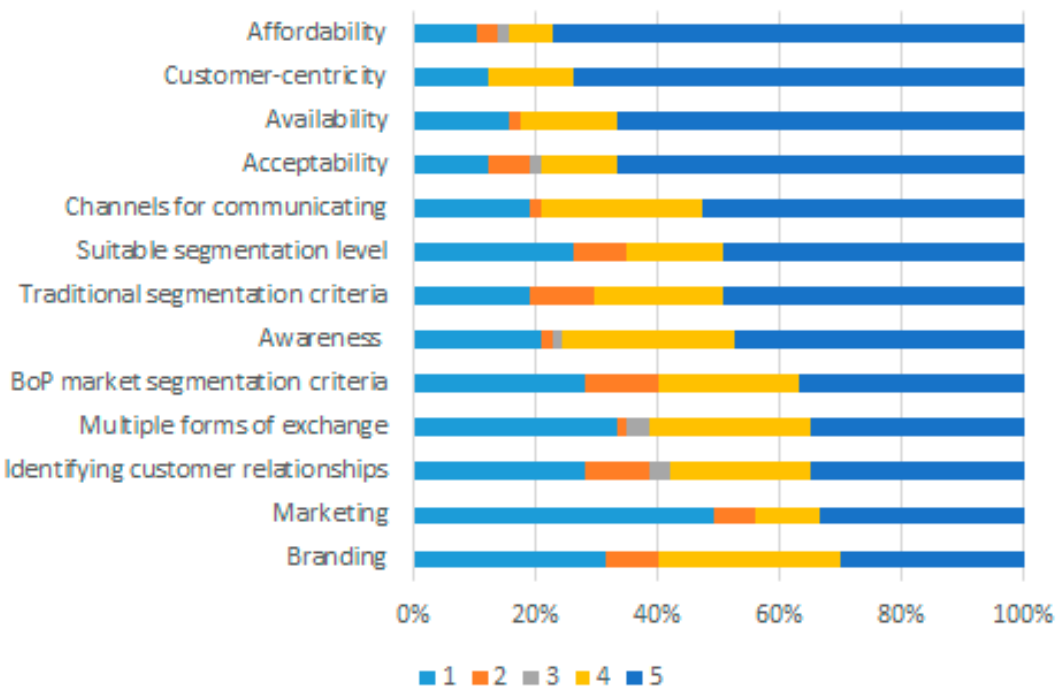

Marketing managerial difficulty

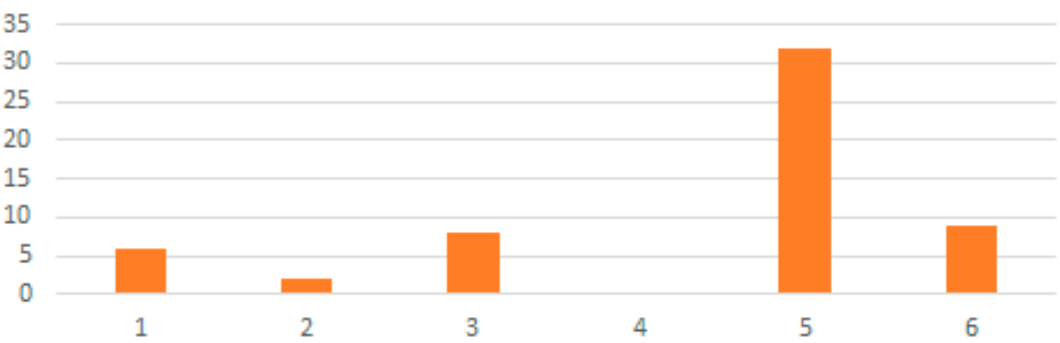

Manner of implementation: Marketing

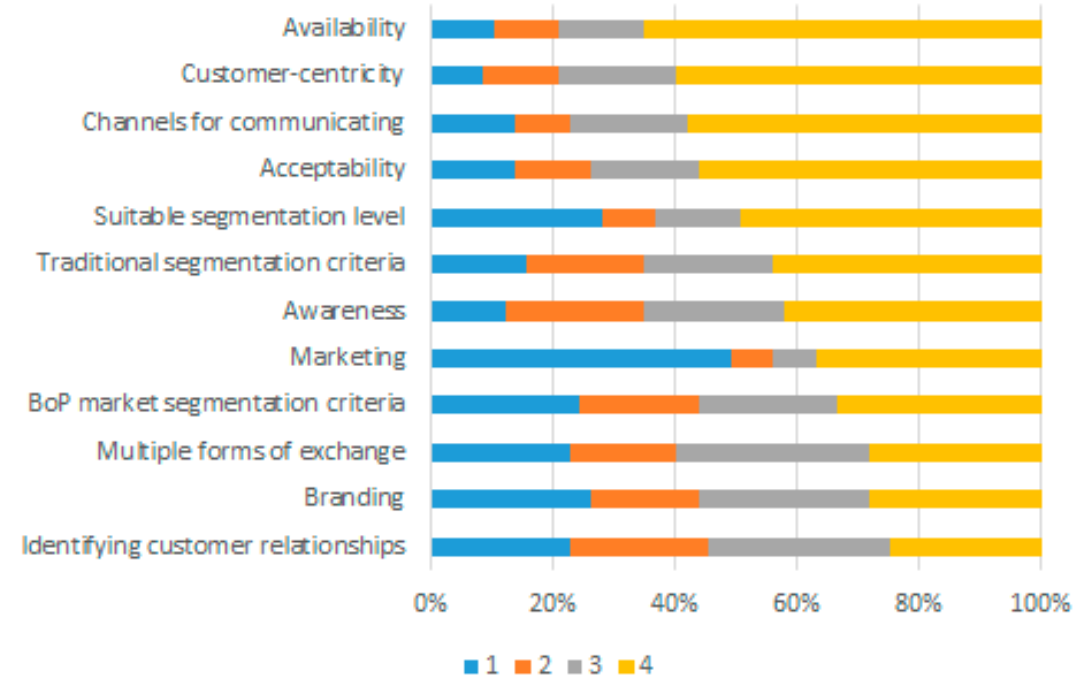

Figure A5. Frequency analysis: Marketing $(\mathrm{N}=57)$. 
Strategic Alliances impact

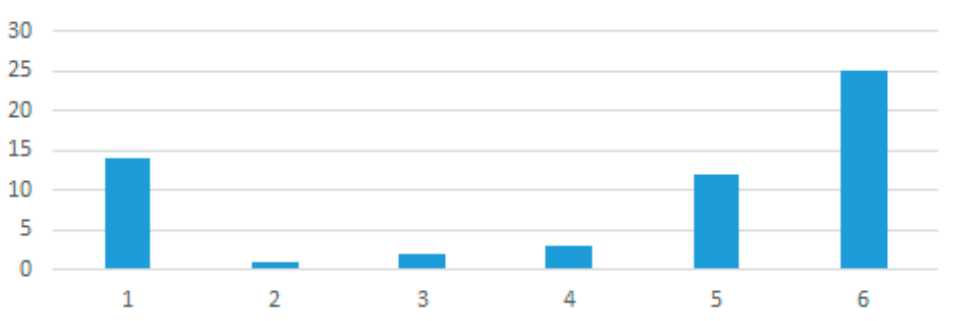

Priority in planning: Strategic Alliances

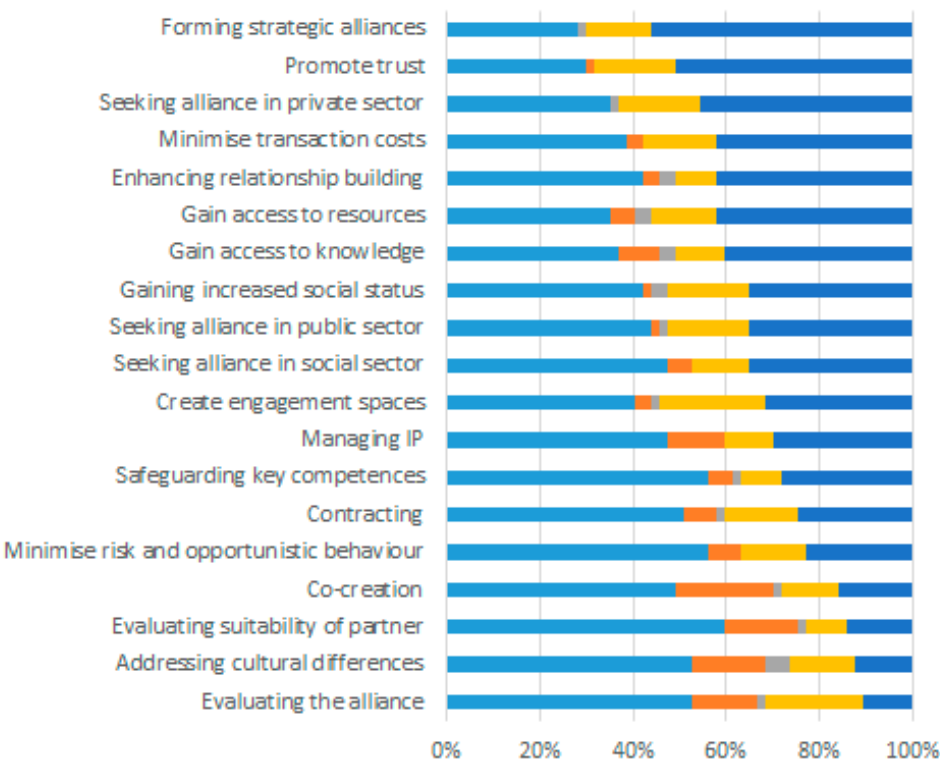

- $1=2=3=4$ | 5
Strategic Alliances managerial difficulty

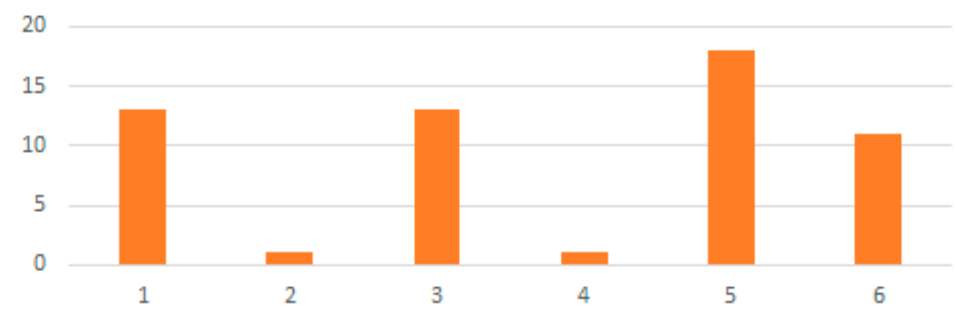

Manner of implementation: Strategic Alliances

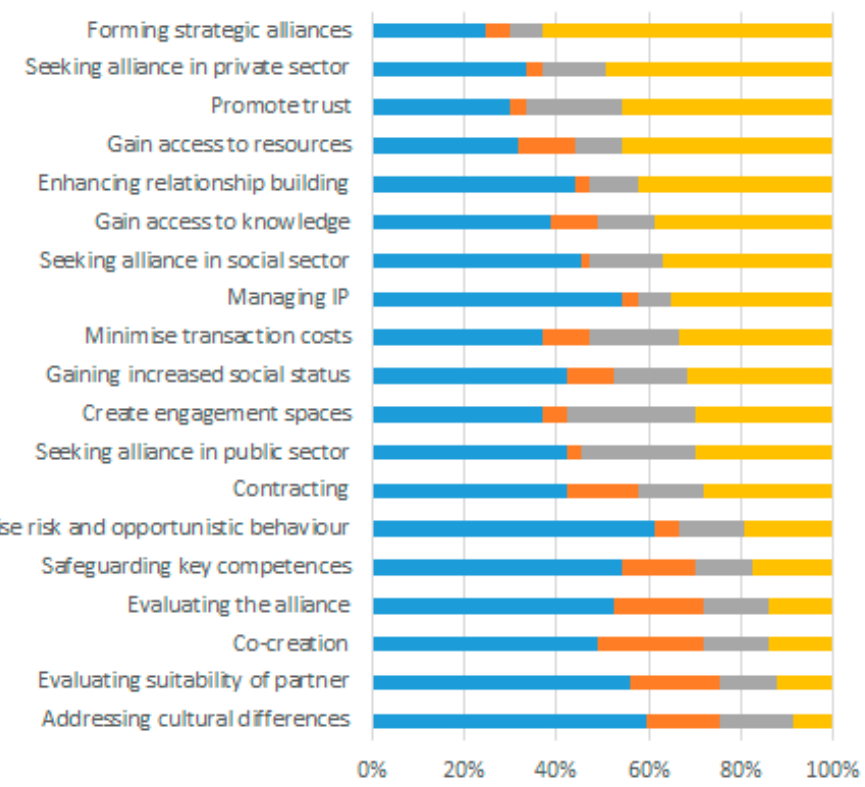

$=1=2-3=4$

Figure A6. Frequency analysis: Strategic Alliances $(\mathrm{N}=57)$. 


\section{References}

1. Hardoon, D. Oxfam Wealth: Having It All and Concentrated in the Hands of a Few. Oxfam Brief. Issue 2015, 12. Available online: https://www-cdn.oxfam.org/s3fs-public/file_attachments/ib-wealth-having-allwanting-more-190115-en.pdf (accessed on 9 October 2020).

2. Prahalad, C.K.; Hammond, A. Serving the world's poor, profitably. Harv. Bus. Rev. 2002, 80, 4-11.

3. Prahalad, C.K.; Di Benedetto, A.; Nakata, C. Bottom of the pyramid as a source of breakthrough innovations. J. Prod. Innov. Manag. 2012, 29, 6-12. [CrossRef]

4. van der Merwe, E.; Grobbelaar, S.; Bam, W. Exploring the functional dynamics of innovation for inclusive development innovation systems: A case study of a large scale maternal mHealth project in South Africa. Innov. Dev. 2019, 10, 117-138. [CrossRef]

5. Van Der Merwe, E.; Grobbelaar, S.S.S. Evaluating inclusive innovative performance: The case of the eHealth system of the Western Cape Region, South Africa. In Proceedings of the PICMET 2016-Portland International Conference on Management of Engineering and Technology: Technology Management For Social Innovation, Honolulu, HI, USA, 4-8 September 2016.

6. Department of Statistics SA. Statistical Release P0211; Department of Statistics SA: Pretoria, South Africa, 2020.

7. Amnesty International. Broken and Unequal: The State of Education in South Africa; Amnesty International: London, UK, 2020.

8. Department National Treasury of South Africa. 2018 Budget Highlights; Department National Treasury of South Africa: Pretoria, South Africa, 2018.

9. NPO Act71 of 1997(1) Republic of South Africa: Government Gazette Staatskoerant; Republic of South Africa: Pretoria, South Africa, 2014; pp. 1-96.

10. IMF. Regional Economic Outlook: Sub-Saharan Africa; IMF: Washing, DC, USA, 2018; ISBN 9781484348895.

11. UNCTAD. The Least Developed Countries Report 2016: The Path to Graduation and Beyond: Making the Most of the Process; UNCTAD: Geneva, Switzerland, 2016; ISBN 9789211129052.

12. Eifert, B.; Ramachandran, V. Competitiveness and Private Sector Development in Africa Cross Country Evidence from the World Bank's Investment Climate Data; The World Bank: Tokyo, Japan, 2004.

13. Gunning, J.W. Determinants of African Manufacturing Investment: The Microeconomic Evidence. J. Afr. Econ. 2001, 10 (Suppl. 2), 48-80. [CrossRef]

14. Perdana, A.A. Risk Management for the Poor and Vulnerable. CSIS Work. Pap. Ser. 2005. Available online: https://ideas.repec.org/p/sis/wpecon/wpe093.html (accessed on 9 October 2020).

15. Loayza, N.V.; Rancière, R.; Servén, L.; Ventura, J. Macroeconomic volatility and welfare in developing countries: An introduction. World Bank Econ. Rev. 2007, 21, 343-357. [CrossRef]

16. Ndulu, B.; Lijane, L.; Ramachandran, V.; Wolgin, J. Challenges of African Growth; The World Bank: Washington, DC, USA, 2007.

17. Raddatz, C. Are External Shocks Responsible for the Instability of Output in Low-Income Countries? World Bank: Washington, DC, USA, 2007.

18. ver Loren van Themaat, T.; Schutte, C.S.; Lutters, D.; Kennon, D. Designing a framework to design a business model for the "Bottom of the pyramid" population. S. Afr. J. Ind. Eng. 2013, 24, 190-204. [CrossRef]

19. Simanis, E.; Hart, S. The Base of the Pyramid Protocol: Toward Next Generation BoP Strategy; Cornell University: New York, NY, USA, 2008; Volume 2.

20. George, G.; McGahan, A.M.; Prabhu, J. Innovation for Inclusive Growth: Towards a Theoretical Framework and Research Agenda. J. Manag. Stud. 2012, 49, 661-683. [CrossRef]

21. Botha, L.; Grobbelaar, S.; Bam, W. Towards a Framework to Guide the Evaluation of Inclusive Innovation Systems. S. Afr. J. Ind. Eng. 2016, 27, 64-78. [CrossRef]

22. Prahalad, C.K. Why selling to the poor makes for good business. Fortune 2004, 150, 32-33.

23. Prahalad, C.K.; Hart, S.L. The fortune at the bottom of the pyramid. Rev. Eletrônica Estratégia Negócios 2010, 1, 1. [CrossRef]

24. Van Der Merwe, M.D.; Grobbelaar, S.S.; Schutte, C.S.L.; Von Leipzig, K.H. Toward an Enterprise Growth Framework for Entering the Base of the Pyramid Market: A Systematic Review. Int. J. Innov. Technol. Manag. 2018, 15, 1850035. [CrossRef]

25. Glaser, B.G.; Strauss, A.L. Discovery of Grounded Theory: Strategies for Qualitative Research; Routledge: New York, NY, USA, 2017. 
26. Corbin, J.M.; Strauss, A. Grounded theory research: Procedures, canons, and evaluative criteria. Qual. Sociol. 1990, 13, 3-21. [CrossRef]

27. Jabareen, Y. Building a conceptual framework: Philosophy, definitions, and procedure. Int. J. Qual. Methods 2009, 8, 49-62. [CrossRef]

28. Durant-law, G. Soft systems methodology and grounded theory combined-a knowledge management research approach? J. Knowl. Manag. 2005, 2, 14-23.

29. Loots, E.; Schutte, C.S.L. Primary Incentive Plan Design Considerations According to a Review of Key Influential Works. Eng. Manag. J. 2016, 28, 224-237. [CrossRef]

30. Osterwalder, A.; Pigneur, Y. Business Model Generation: A Handbook for Visionaries, Game Changers, and Challengers; John Wiley And Sons: Hoboken, NJ, USA, 2010; ISBN 9780470876411.

31. Nidumolu, R.; Prahalad, C.K.; Rangaswami, M.R. Why sustainability is now the key driver of innovation. Harv. Bus. Rev. 2009, 87, 56-64.

32. Akter, S.; Ray, P.; D'Ambra, J. Continuance of mHealth services at the bottom of the pyramid: The roles of service quality and trust. Electron. Mark. 2013, 23, 29-47. [CrossRef]

33. Chikweche, T.; Fletcher, R. Revisiting the marketing mix at the bottom of pyramid (BOP): From theoretical considerations to practical realities. J. Consum. Mark. 2012, 29, 507-520. [CrossRef]

34. Anderson, J.; Markides, C. Strategic Innovation at the Base of the Economic Pyramid Strategic Innovation at the Base of the Economic Pyramid. Harv. Bus. Rev. 2002, 12, 49.

35. Nakata, C.; Weidner, K. Enhancing new product adoption at the base of the pyramid: A contextualized model. J. Prod. Innov. Manag. 2012, 29, 21-32. [CrossRef]

36. Lundvall, B.-Å; Christensen, J.L. Extending and Deepening the Analysis of Innovation Systems-with Empirical Illustrations from the DISKO Project; CopenhagenBusiness School: Frederiksberg, Denmark, 1999.

37. Johnson, S.; Ostry, J.D.; Subramanian, A. Prospects for sustained growth in Africa: Benchmarking the constraints. IMF Staff Pap. 2010, 57, 119-171. [CrossRef]

38. Linna, P.; Richter, U. Technology entrepreneurship-potential for social innovation? The case of Kenyan mobile industry companies. Int. J. Bus. Public Manag. 2011, 1, 42-50.

39. Chatterjee, S. Engaging with an emergent metanarrative: A critical exploration of the BOP proposition. Organization 2014, 21, 888-906. [CrossRef]

40. Prahalad, C.K.; Krishnan, M.S.; Mayuram, S. The New Age of Innovation: Driving Cocreated Value through Global Networks; McGraw-Hill: New York, NY, USA, 2008; ISBN 0071598294.

41. Battilana, J.; Lee, M.; Walker, J.; Dorsey, C. In search of the hybrid ideal. Stanford Soc. Innov. Rev. 2012, 6, 2013.

42. Ansari, S.; Munir, K.; Gregg, T. Impact at the "Bottom of the Pyramid": The role of social capital in capability development and community empowerment. J. Manag. Stud. 2012, 49, 813-842. [CrossRef]

43. London, T.; Hart, S.L. Next Generation Business Strategies for the Base of the Pyramid: New Approaches for Building Mutual Value; FT Press: Upper Saddle River, NJ, USA, 2011; ISBN 0137047894.

44. Reficco, E.; Márquez, P. Inclusive Networks for Building BOP Markets. Bus. Soc. 2012, 51, 512-556. [CrossRef]

45. Heeks, R.; Foster, C.; Nugroho, Y. New models of inclusive innovation for development. Innov. Dev. 2014, 4, 175-185. [CrossRef]

46. Anuja Utz and Carl Dahlman Promoting Inclusive Innovation (India); The World Bank: Washington, DC, USA, 2007; Volume 105.

47. Altenburg, T. Building inclusive innovation systems in developing countries-why it is necessary to rethink the policy agenda. In Proceedings of the IV Globelics Conference, Mexico City, Mexico, 22-24 September 2008; pp. 1-17.

48. Jagtap, S.; Larsson, A.; Kandachar, P. Design and development of products and services at the Base of the Pyramid: A review of issues and solutions. Int. J. Sustain. Soc. 2013, 5, 207-231. [CrossRef]

49. Hamel, G.; Prahalad, C.K. Corporate imagination and expeditionary marketing. Harv. Bus. Rev. 1991, 69, 81-92. [PubMed]

50. Dofsma, W.; Duysters, G.; Costa, I.; Dolfsma, W.; Duysters, G.; Costa, I. Multinationals and Emerging Economies: The Quest for Innovation and Sustainability; Edward Elgar Publishing: Cheltenham, UK, 2009.

51. Immelt, J.R.; Govindarajan, V.; Trimble, C. How GE is disrupting itself. Harv. Bus. Rev. 2009, 87, 56-65.

52. Tu, J.; Shih, M.; Hsu, C.; Lin, J. Developing Blue Ocean Strategy of Sustainable Product Design and Development for Business Opportunities of BOP Groups in Taiwan. Math. Probl. Eng. 2014, 2014, 297524. [CrossRef] 
53. Kim, W.C.; Mauborgne, R. Value innovation: A leap into the blue ocean. J. Bus. Strategy 2005, 26, 22-28.

54. Kim, C.; Yang, K.H.; Kim, J.; Bourletidis, D.; Chan Kim, W.; Mauborgne, R.R.R.; Rawabdeh, I.; Raqab, A.; Al-nimri, D.; Haddadine, S.; et al. Value innovation: A leap into the blue ocean. Omega 2005, 26, 22-28.

55. Foster, C.; Heeks, R. Analyzing policy for inclusive innovation: The mobile sector and base-of-the-pyramid markets in Kenya. Innov. Dev. 2013, 3, 103-119. [CrossRef]

56. Viswanathan, M. Understanding Product and Market Interactions in Subsistence Marketplaces: A Study in South India. Adv. Int. Manag. 2007, 20, 21-57.

57. Karnani, A.G. Fortune at the Bottom of the Pyramid: A Mirage. Forthcoming 2007. Available online: https://papers.ssrn.com/sol3/papers.cfm?abstract_id=914518 (accessed on 9 October 2020).

58. Esposito, M.; Kapoor, A.; Goyal, S. Enabling healthcare services for the rural and semi-urban segments in India: When shared value meets the bottom of the pyramid. Corp. Gov. 2012, 12, 514-533. [CrossRef]

59. Karamchandani, A.; Kubzansky, M.; Lalwani, N. The globe: Is the bottom of the pyramid really for you? Harv. Bus. Rev. 2011, 107. Available online: https://hbr.org/2011/03/the-globe-is-the-bottom-of-the-pyramidreally-for-you (accessed on 9 October 2020).

60. Mahajan, V.; Banga, K. The 86\% Solution: How to Succeed in th Biggest Market Opporutntiy of the 21st Century; Prentice Hall: Upper Saddle River, NJ, USA, 2006; ISBN 0132485060.

61. Nkamnebe, A.D. Globalised marketing and the question of development in the Sub-Saharan Africa (SSA). Crit. Perspect. Int. Bus. 2006, 2, 321-338. [CrossRef]

62. Tidd, J.; Bessant, J.R. Strategic Innovation Management; John Wiley \& Sons: Hoboken, NJ, USA, 2014; ISBN 9781118457238.

63. Johnson, J.D. Innovation and Knowledge Management; Edward Elgar Publishing: Cheltenham, UK, 2005.

64. Foster, C.; Heeks, R. Nurturing user-producer interaction: Inclusive innovation flows in a low-income mobile phone market. Innov. Dev. 2014, 4, 221-237. [CrossRef]

65. Simanis, E.; Hart, S.; Duke, D. The Base of the Pyramid Protocol Beyond "Basic Needs" Business Strategies; MIT Press: Cambridge, MA, USA, 2008; pp. 57-84.

66. Chataway, J.; Hanlin, R.; Kaplinsky, R. Inclusive Innovation: An Architectue for Policy Development. Innov. Dev. 2014, 4.1, 33-54. [CrossRef]

67. Grobbelaar, S.; Tijssen, R.; Dijksterhuis, M. University-driven inclusive innovations in the Western Cape of South Africa: Towards a research framework of innovation regimes. Afr. J. Sci. Technol. Innov. Dev. 2017, 9,7-19. [CrossRef]

68. Cozzens, S.; Sutz, J. Innovation in informal settings: Reflections and proposals for a research agenda. Innov. Dev. 2014, 4, 5-31. [CrossRef]

69. Prahalad, C.K. The Fortune at the Bottom of the Pyramid: Eradicating Poverty Through Profits; Pearson: London, UK, 2009; ISBN 9780137042029.

70. Christensen, C.M.; Raynor, M.E. The Innovator's Solution: Creating and Sustaining Successful Growth; Harvard Business School Press: Boston, MA, USA, 2003; ISBN 9781422196571.

71. Cozzens, S.; Sutz, J. Innovation in informal settings: A research agenda. In Proceedings of the IDRC, Ottawa, ON, Canada, 7-8 February 2012; pp. 1-53.

72. Geroski, P.A. Models of technology diffusion. Res. Policy 2000, 29, 603-625. [CrossRef]

73. Burlea-Schiopoiu, A.; Mihai, L.S. An integrated framework on the sustainability of SMEs. Sustainability 2019, 11, 6026. [CrossRef]

74. Wanasika, I. Strategizing for BOP Markets. Am. J. Manag. 2013, 13, 46-57.

75. Munir, K.; Ansari, S.; Gregg, T. Beyond the hype: Taking business strategy to the "bottom of the pyramid.". Adv. Strateg. Manag. 2010, 27, 247-276.

76. Anderson, J.; Billou, N. Serving the world's poor: Innovation at the base of the economic pyramid. J. Bus. Strategy 2007, 28, 14-21. [CrossRef]

77. Kotler, P.; Keller, K.L. Marketing Management; Pearson Education: London, UK, 2009; ISBN 9780132102926.

78. Kotler, P.; Keller, K.L. Marketing Management: Quattordicesima Edizione; Pearson Education: London, UK, 2012; ISBN 9788871927879.

79. Gummesson, E. Total Relationship Marketing: Rethinking Marketing Management; Butterworth-Heinemann: Oxford, UK, 2002.

80. Gummesson, E. From relationship marketing to total relationship marketing and beyond. J. Serv. Mark. 2017, 31, 16-19. [CrossRef] 
81. Christopher, M.; Payne, A.; Ballantyne, D. Relationship Marketing: Bringing Quality Customer Service and Marketing Together; Butterworth-Heinemann: Oxford, UK, 1991.

82. Anderson, J.; Markides, C. Strategic Innovation at the Base of the Economic Pyramid. MIT Sloan Manag. Rev. 2007, 49, 83-88.

83. Schuster, T.; Holtbrügge, D. Benefits of Cross-sector Partnerships in Markets at the Base of the Pyramid. Bus. Strateg. Environ. 2014, 23, 188-203. [CrossRef]

84. Rivera-Santos, M.; Rufín, C. Global village vs. small town: Understanding networks at the Base of the Pyramid. Int. Bus. Rev. 2010, 19, 126-139. [CrossRef]

85. Wheeler, D.; Mckague, K.; Thomson, J.; Davies, R.; Medalye, J.; Prada, M. Creating Sustainable Local Enterprise Networks. MIT Sloan Manag. Rev. 2005, 47, 33.

86. Dahan, N.M.; Doh, J.P.; Oetzel, J.; Yaziji, M. Corporate-NGO collaboration: Co-creating new business models for developing markets. Long Range Plann. 2010, 43, 326-342. [CrossRef]

87. Seelos, C.; Mair, J. Profitable Business Models and Market Creation in the Context of Deep Poverty: A Strategic View. Acad. Manag. Perspect. 2011, 21, 49-63. [CrossRef]

88. Chesbrough, H.; Ahern, S.; Finn, M.; Guerraz, S. Business Models for Technology in the Developing World: The Role of Non-Governmental Organizations. Calif. Manage. Rev. 2012, 48, 48-61. [CrossRef]

89. Prahalad, C.K.; Mashelkar, R.A. Innovation's Holy Grail. Harv. Bus. Rev. 2010. Available online: https://hbr.org/2010/07/innovations-holy-grail (accessed on 9 October 2020).

90. Dyer, J.H.; Kale, P.; Singh, H. How To Make Strategic Alliances Work. (cover story). MIT Sloan Manag. Rev. 2001. Available online: https://sloanreview.mit.edu/article/how-to-make-strategic-alliances-work/ (accessed on 9 October 2020).

91. Kale, P.; Singh, H. Managing strategic alliances: What do we know now, and where do we go from here? Acad. Manag. Perspect. 2009, 23, 45-62. [CrossRef]

92. Koza, M.; Lewin, A. Managing partnerships and strategic alliances: Raising the odds of success. Eur. Manag. J. 2000, 18, 146-151. [CrossRef]

93. Hoffmann, W.H.; Schlosser, R. Success Factors of Strategic Alliances in Small and Medium-sized Enterprises-An Empirical Survey. Long Range Plann. 2001, 34, 357-381. [CrossRef]

94. Hoffmann, W.H. Strategies for managing a portfolio of alliances. Strateg. Manag. J. 2007, 28, 827-856. [CrossRef]

95. Elkington, J. Accounting for the Tripple Bottom Line. Meas. Bus. Excell. 1998, 2, 18-22. [CrossRef]

96. Alhaddi, H. Triple Bottom Line and Sustainability: A Literature Review. Bus. Manag. Stud. 2015, 1, 6-10. [CrossRef]

97. Jackson, A.; Boswell, K.; Davis, D. Sustainability and Triple Bottom Line Reporting-What is it all about? Int. J. Bus. Humanit. Technol. 2011, 1, 55-59.

98. Hillemann, J.; Verbeke, A. International Business and Sustainable Development; Emerald Group Publishing Limited: Bingley, UK, 2014; Volume 8, ISBN 978-1-78190-989-8.

99. Prahalad, C.K.; Hart, S.L. The Fortune at the Bottom of the Pyramid; Pearson FT Press: Upper Saddle River, NJ, USA, 2002; ISBN 0131467506.

100. Hart, S.; Sharma, S.; Halme, M. Poverty, Business Strategy, and Sustainable Development. Organ. Environ. 2016, 29, 401-415. [CrossRef]

Publisher's Note: MDPI stays neutral with regard to jurisdictional claims in published maps and institutional affiliations.

(C) 2020 by the authors. Licensee MDPI, Basel, Switzerland. This article is an open access article distributed under the terms and conditions of the Creative Commons Attribution (CC BY) license (http://creativecommons.org/licenses/by/4.0/). 